University of Nebraska - Lincoln

DigitalCommons@University of Nebraska - Lincoln

U.S. Environmental Protection Agency Papers

U.S. Environmental Protection Agency

2011

Remediation of NAPL Source Zones: Lessons Learned from Field

Studies at Hill and Dover AFB

John E. McCray

Colorado School of Mines, jmccray@mines.edu

Geoffrey R. Tick

University of Alabama, gtick@geo.ua.edu

James W. Jawitz

University of Florida, jawitz@ufl.edu

John S. Gierke

Michigan Technological University, jsgierke@mtu.edu

Mark L. Brusseau

University of Arizona, brusseau@ag.arizona.edu

See next page for additional authors

Follow this and additional works at: https://digitalcommons.unl.edu/usepapapers

Part of the Civil and Environmental Engineering Commons

McCray, John E.; Tick, Geoffrey R.; Jawitz, James W.; Gierke, John S.; Brusseau, Mark L.; Falta, Ronald W.; Knox, Robert C.; Sabatini, David A.; Annable, Michael D.; Harwell, Jeffrey H.; and Wood, A. Lynn, "Remediation of NAPL Source Zones: Lessons Learned from Field Studies at Hill and Dover AFB" (2011). U.S. Environmental Protection Agency Papers. 89.

https://digitalcommons.unl.edu/usepapapers/89

This Article is brought to you for free and open access by the U.S. Environmental Protection Agency at DigitalCommons@University of Nebraska - Lincoln. It has been accepted for inclusion in U.S. Environmental Protection Agency Papers by an authorized administrator of DigitalCommons@University of Nebraska - Lincoln. 


\section{Authors}

John E. McCray, Geoffrey R. Tick, James W. Jawitz, John S. Gierke, Mark L. Brusseau, Ronald W. Falta, Robert C. Knox, David A. Sabatini, Michael D. Annable, Jeffrey H. Harwell, and A. Lynn Wood 


\title{
grownd

\section{Remediation of NAPL Source Zones: Lessons Learned from Field Studies at Hill and Dover AFB}

by John E. McCray ${ }^{1}$, Geoffrey R. Tick², James W. Jawitz ${ }^{3}$, John S. Gierke ${ }^{4}$, Mark L. Brusseau ${ }^{5,6}$, Ronald W. Falta ${ }^{7}$, Robert C. Knox ${ }^{8}$, David A. Sabatini ${ }^{9}$, Michael D. Annable ${ }^{10}$, Jeffrey H. Harwell ${ }^{11}$, and A. Lynn Wood ${ }^{12}$

\begin{abstract}
Innovative remediation studies were conducted between 1994 and 2004 at sites contaminated by nonaqueous phase liquids (NAPLs) at Hill and Dover AFB, and included technologies that mobilize, solubilize, and volatilize NAPL: air sparging (AS), surfactant flushing, cosolvent flooding, and flushing with a complexingsugar solution. The experiments proved that aggressive remedial efforts tailored to the contaminant can remove more than $90 \%$ of the NAPL-phase contaminant mass. Site-characterization methods were tested as part of these field efforts, including partitioning tracer tests, biotracer tests, and mass-flux measurements. A significant reduction in the groundwater contaminant mass flux was achieved despite incomplete removal of the source. The effectiveness of soil, groundwater, and tracer based characterization methods may be site and technology specific. Employing multiple methods can improve characterization. The studies elucidated the importance of smallscale heterogeneities on remediation effectiveness, and fomented research on enhanced-delivery methods. Most contaminant removal occurs in hydraulically accessible zones, and complete removal is limited by contaminant mass stored in inaccessible zones. These studies illustrated the importance of understanding the fluid dynamics and interfacial behavior of injected fluids on remediation design and implementation. The importance of understanding the dynamics of NAPL-mixture dissolution and removal was highlighted. The results from these studies helped researchers better understand what processes and scales are most important to include in mathematical models used for design and data analysis. Finally, the work at these sites emphasized the importance and feasibility of recycling and reusing chemical agents, and enabled the implementation and success of follow-on full-scale efforts.
\end{abstract}

${ }^{1}$ Corresponding author: Environmental Science and Engineering Division, Colorado School of Mines, Golden, C0 80401; (303) 273-3490; jmccray@mines.edu

${ }^{2}$ Department of Geological Sciences, University of Alabama, Tuscaloosa, AL 35487; (205) 348-4293; gtick@geo.ua.edu

${ }^{3}$ Soil Water and Science Department, University of Florida, Gainesville, FL 32611; (352) 392-1951; jawitz@ufl.edu

${ }^{4}$ Department of Geological \& Mining Engineering \& Sciences, Michigan Technological University, Houghton, MI 49931;

487-2535; jsgierke@mtu.edu

${ }^{5}$ Department of Soil, Water, and Environmental Science, University of Arizona, Tucson, AZ 85721.

${ }^{6}$ Department of Hydrology and Water Resources, University of Arizona, Tucson, AZ 85721; (520) 621-3244; brusseau@ag.arizona.edu

${ }^{7}$ Department of Environmental Engineering and Earth Science, Clemson University, Clemson, SC 29634; (864) 656-0125; faltar@clemson.edu

${ }^{8}$ School of Civil Engineering and Environmental Science, University of Oklahoma, Norman, OK 73019; (405) 325-4212; rknox@ou.edu

${ }^{9}$ School of Civil Engineering and Environmental Science, University of Oklahoma, Norman, OK 73019; (405) 325-4273; sabatini@ou.edu

${ }^{10}$ Department of Environmental Engineering Sciences, University of Florida, Gainesville, FL 32611; (352) 392-3294; annable@ufl.edu

${ }^{11}$ University of Oklahoma, School of Chemical, Biological, and Materials Engineering, University of Oklahoma, Norman, OK 73019; (405) 325-4375; jharwell@ou.edu

${ }^{12}$ Ground Water and Ecosystems Restoration Division, National Risk Management Research Laboratory, U.S. Environmental Protection Agency, Ada, OK 74821; (580) 436-8552; wood.lynn@epa.gov

Received January 2010, accepted November 2010.

(C) 2011, The Author(s)

Ground Water (c) 2011, National Ground Water Association.

doi: $10.1111 / j .1745-6584.2010 .00783 . x$

This article is a U.S. government work, and is not subject to copyright in the United States. 


\section{Introduction and Background}

Intensive field studies were conducted between 1994 and 1996 (Rao et al. 1997; Shiau et al. 1997; Annable et al. 1998a, 1998b; Jawitz et al. 1998a, 1998b, 2003b; McCray and Brusseau 1998; Wojick 1998; Bedient et al. 1999; Brusseau et al. 1999a; Falta et al. 1999a, 1999b; Gierke et al. 1999a, 1999b; Sabatini et al. 1999; Cain et al. 2000; Alter et al. 2003; Sandrin et al. 2004) at Hill AFB, and between 1998 and 2002 at Dover AFB (Brooks et al. 2002, 2004; Tick et al. 2003; Childs et al. 2006) to test the ability of various subsurface remediation technologies to remove nonaqueous phase liquid (NAPL) source-zone mass, and to gain a better understanding of the field-scale mass-transfer processes and limitations. Characterization and tracer studies were also conducted as part of this effort. These studies were initiated and managed by the U.S. EPA and were primarily funded by the U.S. Department of Defense's Strategic Environmental Research and Development Program (DoD-SERDP) (Wood and Enfield 2005). The lessons learned from these remediation experiments provided a significant contribution compared to many practical applications because the research funding enabled significantly more monitoring, characterization, and data analysis.

Field test facilities were designed and constructed by U.S. EPA and groups from five academic research institutions conducted enhanced remediation experiments at both field sites: Clemson University, Michigan Technological University, University of Arizona, University of Florida, and University of Oklahoma. Technologies tested included enhanced solubilization techniques (e.g., using surfactants, cosolvents, and complexing-sugar agents), NAPL mobilization techniques (using surfactants and alcohols), and AS. These technologies can be categorized as "enhanced flushing" technologies.

The use of enhanced-flushing technologies has emerged as a promising technique for the remediation of sites contaminated with immiscible liquids. The presence of immiscible organic liquids is generally considered to be the single most important factor limiting remediation of sites contaminated by organic compounds (NRC 1999, 2000, 2005; U.S. EPA 2003, 2007; Wood and Enfield 2005). Zones of immiscible-liquid within the subsurface serve as long-term sources of contamination as it dissolves, often resulting in extensive groundwater plumes. This paper focuses on the enhanced flushing experiments and the site characterization methods used, including tracer tests.

\section{Site Descriptions}

\section{Hill AFB Location and Hydrogeology}

The field site is located within Operable Unit One (OU1) at Hill AFB in Layton, Utah. The site is within the Weber River Valley, approximately 25 miles north of Salt Lake City, Utah. The unit of concern is a shallow, unconfined aquifer that consists of fine-to-coarse sand interbedded with gravel and clay stringers and is approximately $9 \mathrm{~m}$ thick. The natural groundwater elevation at the site fluctuates between 5.5 and $7.5 \mathrm{~m}$ below ground surface (bgs). A 60-m thick clay unit, interbedded with silt, underlies the aquifer at 8 to $9 \mathrm{~m}$ bgs. The saturated thickness ranges from 0 to $3 \mathrm{~m}$ above the clay unit. The aquifer has a horizontal hydraulic conductivity of about $0.05 \mathrm{~cm} / \mathrm{s}$ and an effective porosity of $20 \%$. The average vertical hydraulic conductivity of the clay unit is less than $10^{-7} \mathrm{~cm} / \mathrm{s}$ based on constant-head testing of core samples collected from the unit (Brusseau et al. 1999a). Several waste sites areas are located within OU1 that were in operation at various times between 1940 and 1978. These included chemical disposal pits (primarily waste fuel and spent solvents), inactive fire training areas (jet fuel, oil, and combustible waste chemicals) and a landfill (industrial sludge, waste solvents, and unidentified chemicals), and a phenol/oil pit. The treatment cells used in this study were located adjacent to the disposal pits. The cells were emplaced in what is considered to be a NAPL source area. The NAPL mixture is comprised primarily of petroleum hydrocarbons, chlorinated hydrocarbons, and PAHs, and is less dense than water. The NAPL is smeared throughout the saturated, as well as unsaturated, portions of the aquifer as a result of water table fluctuations. The initial NAPL saturation within the cells ranged from $4 \%$ to $13 \%$, primarily as residual saturation (Table 1), based on results obtained from partitioning tracer tests (PTTs) (e.g., Annable et al. 1998a; Gierke et al. 1999b; Cain et al. 2000). Twelve target contaminants were chosen for the purpose of evaluating remediation effectiveness: trichloroethene (TCE), 1,1,1trichloroethane (TCA), naphthalene (NAP), o-xylene (o-XYL), m,p-xylene (p-XYL), toluene (TOL), benzene (BENZ), ethylbenzene (EB), 1,2-dichlorobenzene (DCB), 1,2,4-trimethylbenzene (TMB), decane (DEC), and undecane (UND). These compounds comprise slightly less than $10 \%$ of the total NAPL within the cell. The remainder was comprised primarily of higher molecular-weight jet fuel components and relatively insoluble, pitch-like components, some of which could not even be extracted using a solvent (Rao et al. 1997; Brusseau et al. 1999a).

\section{Dover AFB Location and Hydrogeology}

Numerous field-scale remediation experiments were conducted at the Groundwater Remediation Field Laboratory (GRFL) at the Dover National Test Site (DNTS) at Dover Air Force Base to assess the effectiveness of immiscible-liquid source-zone removal. These fieldscale remediation tests implemented the use of innovative flushing technologies to increase the removal of immiscible phase contaminant from the saturated zone (groundwater systems). The DNTS was created to investigate innovative remediation technologies for the cleanup or containment of chlorinated-solvent-contaminated groundwater. The DNTS was located in an uncontaminated region of Dover Air Force Base. DNTS was established to provide a facility in which source-zone remediation technology experiments could be conducted following controlled dense nonaqueous phase liquid (DNAPL) releases. 


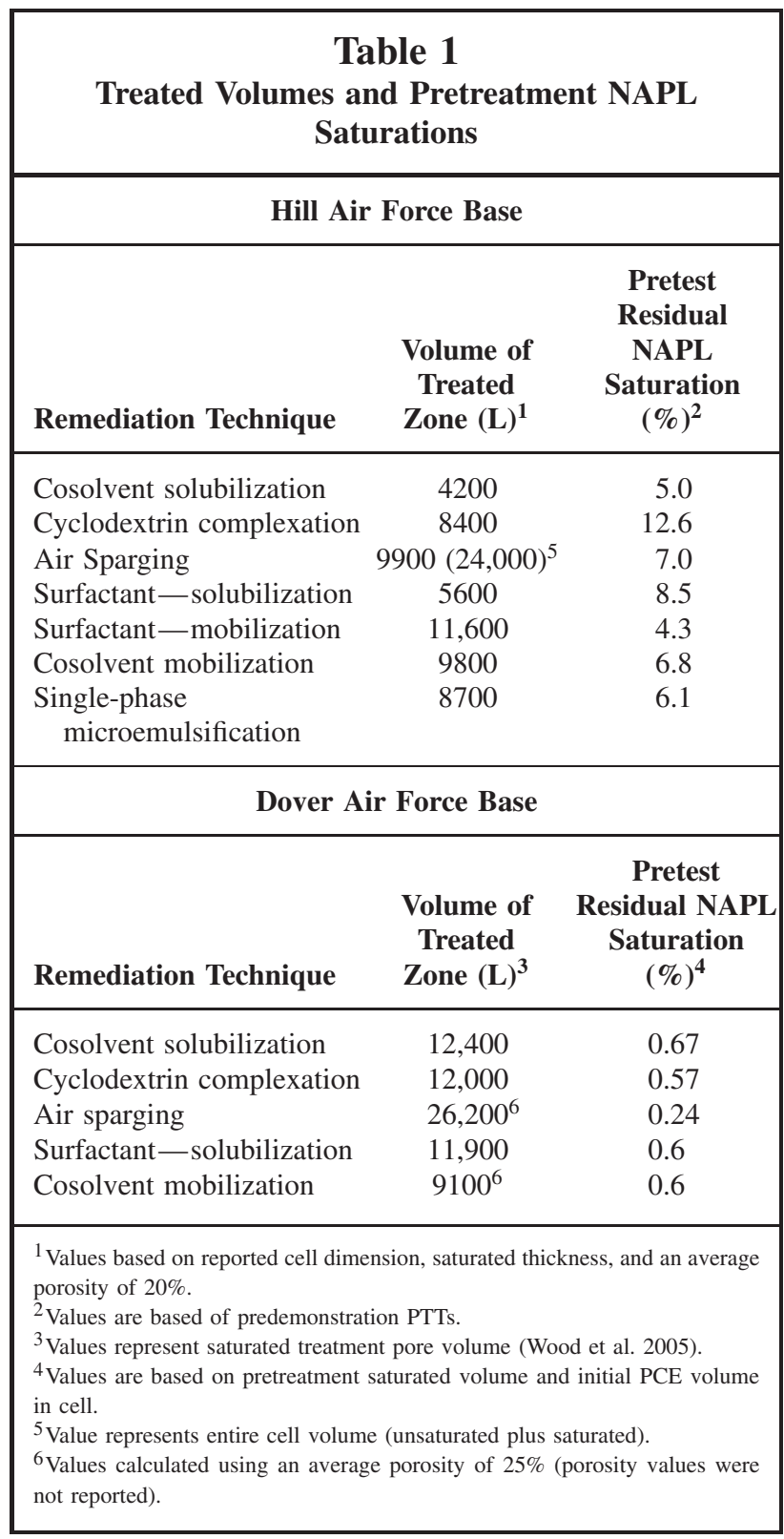

Two test cells (Test Cell \#2 and Test Cell \#3) were constructed at the site and isolated from the aquifer unit underlying the region. The hydrogeologic unit of concern, the Columbia Formation, is a shallow unconfined aquifer that consists of medium to fine sands with interbedded gravels, silts, and clays lenses. Depth to groundwater in the Columbia Formation can vary between 4.5 and $9 \mathrm{~m}$, and the saturated thickness varies between 4 and $7 \mathrm{~m}$. The Columbia Formation is underlain by the Calvert Formation, a silty-clay aquitard varying in thickness between 5.5 and $8.5 \mathrm{~m}$ and present about 9 to $12 \mathrm{~m}$ below the ground surface (bgs). Based on pumping tests conducted at the site, the saturated portion of the aquifer has average horizontal hydraulic conductivities ranging between approximately $2.8\left(10^{-3}\right) \mathrm{cm} / \mathrm{s}$ and $1.2\left(10^{-2}\right) \mathrm{cm} / \mathrm{s}$ (Wood and Enfield 2005). Small-scale vertical variations in hydraulic conductivity have been found to range as much as 2.5 orders of magnitude and may be related to changes in soil type. Porosities between $17 \%$ and $28 \%$ were estimated from the results of conservative tracer tests and field measurement conducted at the site (Brooks et al. 2002; Wood and Enfield 2005).

\section{Test Cell Specifications}

At both field sites, each remediation technology was employed in completely enclosed subsurface test cells to minimize the concern of contaminant and flushing agent release and to enable more aggressive testing for research. At both sites, each test cell was enclosed using Waterloo ${ }^{\circledR}$ sheet piling $(9.5$-mm thick) with sealed interlocking joints or sheet piling that was modified with an additional cavity at the joint to permit grouting to form a watertight seal (Wood and Enfield 1999). Figure 1 shows the experimental set up at Dover AFB. The sheet piles were driven into the clay aquitard to depths of $\sim 14 \mathrm{~m}$ bgs at Dover AFB Test Site and $\sim 10 \mathrm{~m}$ bgs at Hill AFB Test Site. At Hill AFB, each technology employed one test cell. At Dover AFB, two test cells were utilized for all technology demonstrations. The two Dover test cells were enclosed by another sheet pile barrier as a secondary containment measure. Dover and Hill cells had dimensions of $3.0 \times 4.6 \mathrm{~m}^{2}$. Both sites were
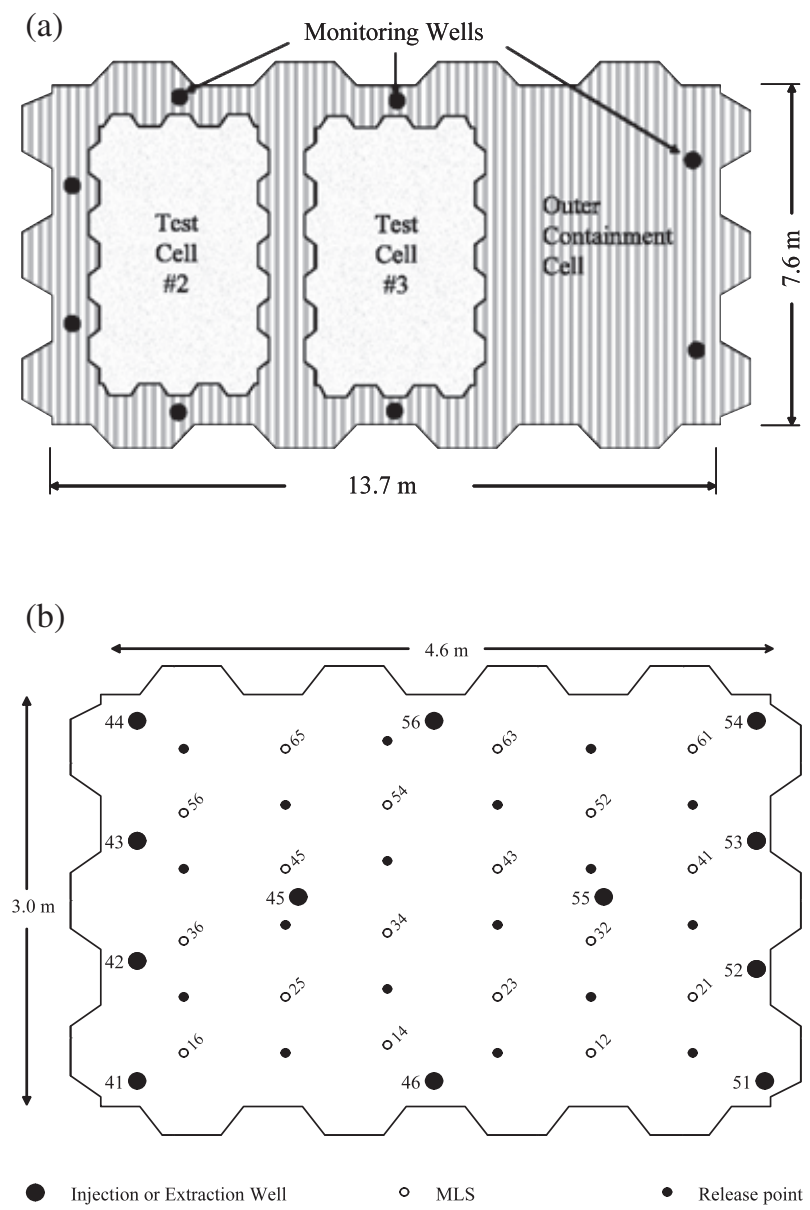

Figure 1. Treatment cells used for the remediation field experiments. (a) Test-cell layout at Dover AFB; (b) example groundwater well configuration for cells (solid circles are injection/extraction wells, and open circles are wells with multidepth samplers). 
highly instrumented to obtain a 3-D sampling network. Dover included 12 wells, 18 DNAPL release points, and 18 multilevel samplers (MLSs) screened at five depths screened $0.3 \mathrm{~m}$ apart, while Hill included seven wells (three injection and three extraction wells), and 12 MLS screened at five depths. At both sites, wells were screened over most of the saturated zone with the bottoms set at $0.3 \mathrm{~m}$ into the confining clay layers. The DNAPL release tubes at Dover extended from the surface to $10.7 \mathrm{~m} \mathrm{bgs}$, and were interspersed among the samplers. Natural groundwater levels in the test cells generally ranged between 8 to $10 \mathrm{~m}$ bgs (Dover) and 3 to $4 \mathrm{~m} \mathrm{bgs}$ (Hill) prior to each experiment. For details of test cells and instrumentation at the Hill and Dover sites, the reader is referred to (Brusseau et al. 1999a; Wood and Enfield 1999, 2005; Brooks et al. 2002; Tick et al. 2003; Childs et al. 2004, 2006). The remediation "treatment zone" for each technology at both Hill and Dover is assumed to include the entire saturated thickness within each test cell, and treatment-zone volumes are reported in Table 1.

\section{Controlled Tetrachloroethene Release at Dover AFB}

The contamination at Hill was historic, while the DNAPL contamination at Dover was emplaced by controlled release. At Dover, release of tetrachloroethene (PCE) into the test cells was approved by the Delaware Department of Natural Resources and Conservation (Wood and Enfield 2005). U.S. EPA researchers released known volumes of PCE into the test cell prior to each remedial demonstration. To simulate a more realistic field scenario, information on the volume and distribution of the PCE released was withheld from the researchers until the completion of tracer tests and remediation experiments. Pilot field-scale remediation flushing experiments were conducted subsequent to each controlled release of pure-phase immiscible liquid PCE. This aspect of the experiments was critical because it allows for massbalance calculations and robust assessments of the remediation technology efficiency and effectiveness. The PCE controlled release was conducted in such a manner as to create an environment that represents, to the best extent practical, conditions similar at hazardous waste sites where these technologies may have application. Each targeted DNAPL release resulted in local residual saturations of $\sim 5$ to $10 \%$ (Brooks et al. 2002), which are similar to those reported for Hill AFB, although treatment-zone averaged saturations at Dover were less than 1\% (Table 1). To encourage residual NAPL saturations in the targeted flushing zones and limit DNAPL pooling within the test cell, the water table elevation was lowered to just below the injection points prior to PCE injection (Wood and Enfield 2005). The water table was then raised in a manner to avoid interaction with the PCE above the injection point and minimize pooling.

\section{Technology Implementation and Discussion}

The technologies implemented at both Hill AFB and Dover AFB include: AS to remove contaminants from below the water table via volatilization and evaporation; aqueous-phase flushes intended to enhance solubilization of contaminants from the NAPL phase into the flowing aqueous phase using complexing sugars, surfactants, and alcohols; and mobilization technologies that move the NAPL phase by reducing its interfacial tension and/or by partitioning into the NAPL and reducing its density (surfactants and alcohols). Each of these technologies is considerably more effective at mass removal than traditional pump and treat. Solubilization technologies have the advantage of not causing NAPL mobilization, which is often considered undesirable by regulatory agencies. Mobilization technologies do present a risk of NAPL movement but are expected to be more efficient at mass removal than enhanced solubilization. AS is only appropriate for volatile contaminants, and is limited by low hydraulic-conductivity and capillary barriers typical of horizontal stratification, but can be more cost effective when its use is appropriate because air is cheaper to deliver, collect, and treat compared to water. The implementation of each technology is described below. General results that are relevant for all technologies, including contaminant mass removal, treatment volume, and initial NAPL saturations, are presented in Tables 1 to 3. No apparent relationship between the mass removal and degree of initial contamination (i.e., initial NAPL saturation) or treatment zone volume was determined for either site (Table 1), thus differences in mass removal are attributed to differences in technology performance or to chemical and physical heterogeneity of the NAPL source. A discussion of the performance of individual technologies at both sites is first presented, followed by discussion of the most pertinent lessons learned from all technologies and both sites.

\section{Air Sparging}

$\mathrm{AS}$ is a treatment technique for removing dissolved, sorbed, and NAPL volatile contaminants from aquifers. Air is injected below the water table to volatize NAPL contaminants in situ, and subsequently moves the gasphase contaminants upward into the vadose zone where vapors are captured by a soil vapor extraction (SVE) systems. For contaminants that degrade aerobically, both AS and SVE enhance degradation by supplying oxygen with the incoming air. Michigan Technological University implemented this technology at Hill AFB and Dover AFB.

Soil vapor extraction systems have undergone relatively numerous field performance tests, and as a remediation technology it is considered a presumptive remedy for fuel and solvent contamination (cf. Gierke 2000). There have been few comprehensive evaluations of AS performance and, especially at the time of these tests, very little data-driven information existed with regard to treatment effectiveness. Thus the primary focus of the performance evaluations of AS coupled with soil vapor extraction treatment was to measure the ability of AS to remove contamination from groundwater.

The Hill AFB NAPL was overall not very volatile but some constituents were amenable to volatilization and 


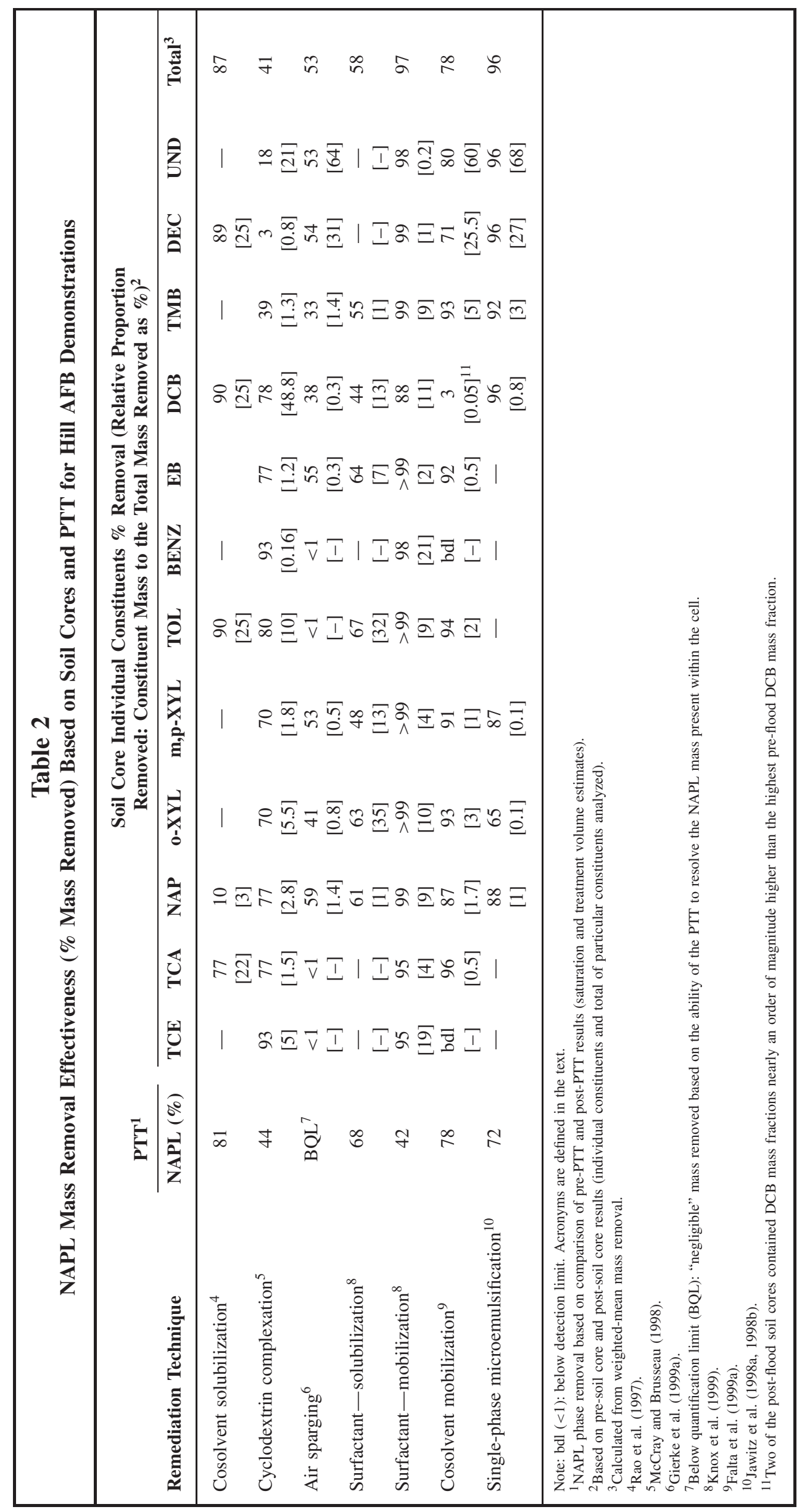


Table 3

PCE Mass Removal Effectiveness (\% Mass Removed) for Dover AFB Demonstrations

\begin{tabular}{|c|c|c|c|c|c|c|}
\hline Remediation Technique & PTT $^{1}$ & PTT $^{2}$ & Flushing $^{3}$ & Initial Vol $(L)^{4}$ & Vol Removed $(\mathrm{L})^{5}$ & Efficiency $^{6}$ \\
\hline Cosolvent solubilization $^{7}$ & $77 \%$ & $92 \%$ & $64 \%$ & 83 & 53 & $6 \mathrm{E}-4$ \\
\hline Cyclodextrin complexation ${ }^{8}$ & $42 \%$ & $\mathrm{n} / \mathrm{a}$ & $48 \%$ & 69 & 33 & $4 \mathrm{E}-4$ \\
\hline Air sparging 9 & $110 \%$ & $93 \%$ & $88-90 \%$ & 64 & 57 & $1 E-6^{10}$ \\
\hline Surfactant-solubilization 7,11 & $47 \%$ & $9 \%$ & $65 \%$ & 70 & 45 & $3.5 \mathrm{E}-4$ \\
\hline Cosolvent mobilization $^{9}$ & - & $\mathrm{n} / \mathrm{a}$ & $78 \%$ & 57 & 44 & $2 \mathrm{E}-4$ \\
\hline \multicolumn{7}{|c|}{$\begin{array}{l}\text { Note: n/a: no post-PTT conducted. } \\
{ }^{1} \text { On the basis of PTT determined initial saturations and actual PCE removed by flushing. } \\
{ }^{2} \text { On the basis of PTT-determined initial and final saturations. } \\
{ }^{3} \text { On the basis of actual PCE volume present within the cell and the PCE volume removed by flushing. } \\
{ }^{4} \text { On the basis of PCE volumes released by EPA and volumes left over from previous demonstration. } \\
{ }^{5} \mathrm{PCE} \text { volume removed through flushing (combined effluent moment analysis). } \\
{ }^{6} \text { Total volume PCE removed/total volume of treatment solution flushed. } \\
{ }^{7} \text { Brooks et al. (2002, 2004). } \\
{ }^{8} \text { Tick et al. (2003). } \\
{ }^{9} \text { Wood and Enfield (2005). } \\
{ }^{10} \text { It should be noted that comparing air volumes flushed to remedial aqueous solution flushed does not represent similar conditions. } \\
{ }^{11} \text { Childs et al. (2006). }\end{array}$} \\
\hline
\end{tabular}

some susceptible to aerobic degradation (Gierke et al. 1999a). Target chemicals were analyzed in liquid-liquid extractions of soils and NAPL sampled from soil cores, groundwater samples, and soil gas. NAPL removal was determined by comparing pre- and post-treatment PTTs. Removal rates were determined by monitoring the offgas from the SVE system. For Dover AFB, all of the contamination was present below the groundwater table, so the SVE system was capturing the contamination volatized by the AS system. The contamination at Dover was PCE, which is highly volatile but not very degradable under aerobic conditions.

The AS/SVE system configurations at both sites were similar in that there were two centrally located sparge wells in the saturated zone and six vapor extraction vents in the unsaturated zone around the inside perimeter of the cell. The sparge wells were screened in the bottom-most portion of the aquifer, above the clay layer at the bottom. The six SVE vents were screened in the bottom half of the unsaturated zone. The surfaces of both cells were sealed in an attempt to maximize the capture effectiveness of the SVE vents for the sparge air. Sparging and extraction rates were different due to the different hydraulic conductivities of the sediments at each site. The intermediate samplers were also different due to the differences in depths to the water table at the two sites.

In the setting where the contamination was predominantly low-volatility compounds (Test Cell 1 at Hill), very little NAPL removal $(<10 \%$ by volume) was observed based on pre-/post-PTTs (Gierke et al. 1999a, 1999b) (Table 2). Nevertheless, volatile constituents were removed by volatilization even when present in trace quantities (Gierke et al. 1999a; Wojick 1998). Laboratory column experiments under ideal one-dimensional flow conditions demonstrated that at most about $15 \%$ of the NAPL in Test Cell 1 would be volatilized under ambient temperature conditions (Gierke et al. 1999b). Although the PTTs conducted in the column experiments could conclusively measure at least a $10 \%$ decrease in NAPL volume, the reduction of NAPL volume due to sparging in Test Cell 1 was less than the precision of the field PTTs (Gierke et al. 1999a).

Over $80 \%$ of the PCE present in Test Cell 1 at Dover was volatilized by AS and effectively captured by the SVE system (Wood and Enfield 2005) (Table 3). The removal rate of PCE was high at first, but approached asymptotically low rates after about 2 weeks of sparging (Figure 2). Altering the sparging rates did not alter the removal rate, presumably because the sparge air had removed the majority of the PCE in proximity to the sparge air channels and changing the sparge rates did not influence the distribution of the sparge air (Taege 2002; van Antwerp et al. 2008). Although pulsing air injection improved PCE removal rates in the lab experiments (Heron et al. 2002), pulsing had practically no effect on overall average removal rates in the field. Pumping the groundwater during sparging, however, did result in a significant increase in contaminant removal (Taege 2002).

A multiphase, multidomain, transport model (TMVOC) was able to simulate the removal of PCE by AS in a two-dimensional box experiment with only the mass transfer rate having to be calibrated (Heron et al. 2002; van Antwerp et al. 2008). Even though the laboratory experiment was configured to be similar to the fieldscale tests, the calibrated laboratory mass transfer rate was three orders of magnitude greater than the mass transfer rate calibrated to the field test results (van Antwerp et al. 2008), likely due to the larger diffusion distances in the field (a simple approximation of the mass transfer rate is the effective liquid diffusion coefficient divided by an effective diffusion distance squared). The air channel spacing was larger in the field due to heterogeneities, and distance between NAPL zones was likely larger than in the lab apparatus. The model could simulate the field 


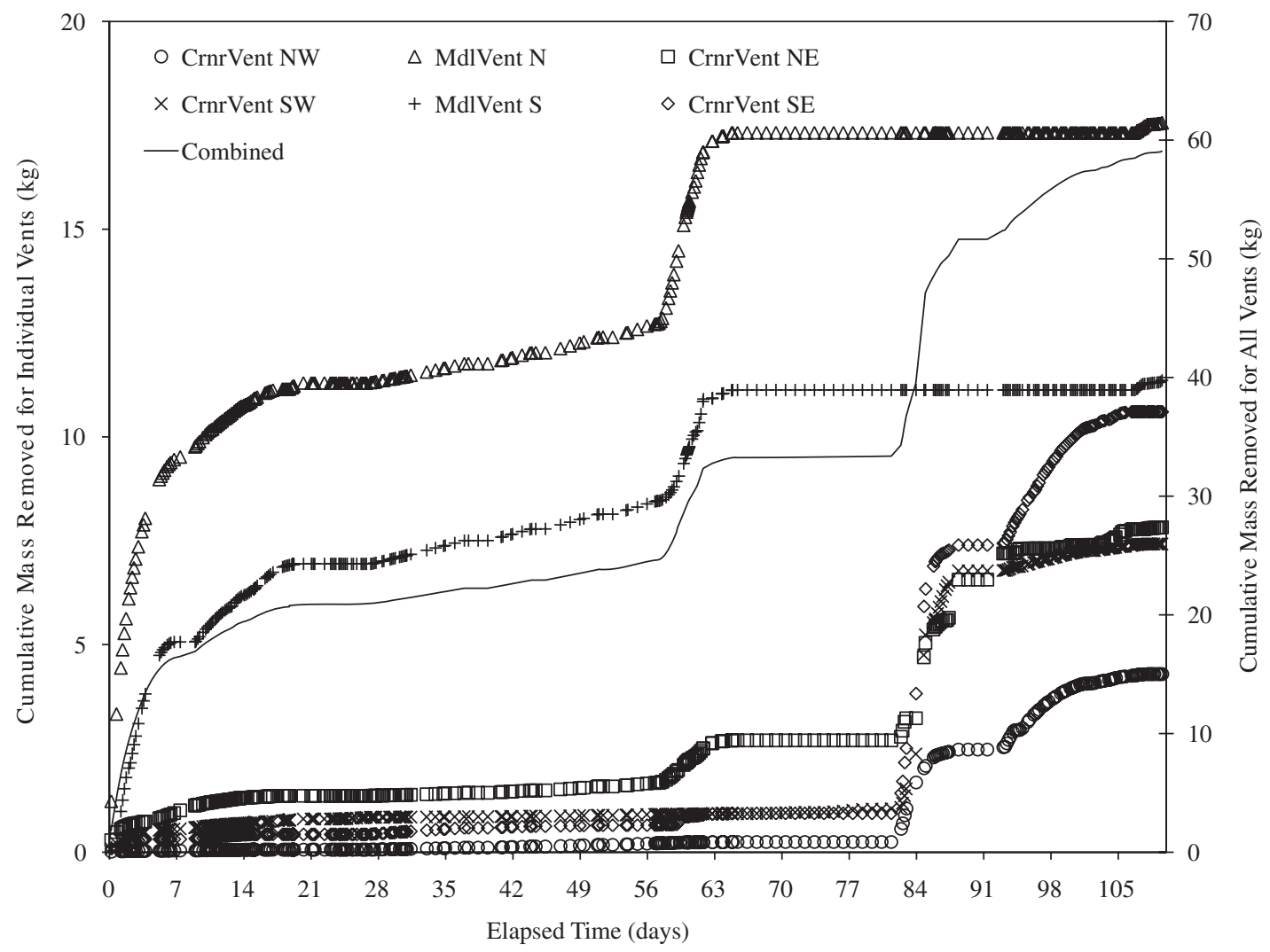

Figure 2. PCE mass removed during sparging at the Dover Test Cell.

results using independently derived parameters, except for the mass transfer rate, which had to be calibrated.

Contact between the flowing air and contamination is the primary requisite for timely removal of the volatile fraction. Diffusion is too slow for effective removal by volatilization. Sparge air tends to flow in a very heterogeneous fashion, both in the field and in laboratory experiments (Hein et al. 1997; Wojick 1998; Castor 2002; Heron et al. 2002; Taege 2002). Heterogeneous sparge air flows coupled with heterogeneous distributions of contamination will result in imperfect air/contaminant contact, so vapor concentrations tend to be much lower than concentrations in equilibrium with NAPL phase, and concentrations diminish rapidly after the start of remediation as the contamination in direct contact with the sparge is removed readily (van Antwerp et al. 2008). Higher sparging rates yield higher removal rates when the distribution and extent of the sparged air increases (Heron et al. 2002; Taege 2002). Pulsing sparge flows will result in very temporary spikes in removal concentrations, but these gains in concentration are so short lived that there is no net increase in removal rate averaged over the entire remediation duration (e.g., McCray and Falta 1997; McCray 2000). Additional contact with the flowing air can be achieved by moving the contaminated groundwater to the sparge zone, which results in higher contaminant removal efficiency. Actively moving contaminated water into or through the sparge zone is more effective. It is important to monitor the contaminant concentrations in extraction vents and pumping wells to quantify the overall removal. In situ monitoring locations were not helpful in both of the sparging tests to ascertain either the location of the contamination or the spatial effectiveness of sparging. The representativeness of the in situ monitoring data for sparging is questionable.

\section{Complexing-Sugar Flush for Enhanced NAPL Solubilization}

Cyclodextrin is a polycyclic oligosaccharide molecule having a toroidal or lampshade-shaped structure with a hydrophobic interior and a hydrophilic exterior. Relatively nonpolar organic contaminants partition to the interior of the molecule forming an inclusion complex, while the highly polar exterior provides the molecule with a large aqueous solubility (approximately $50 \%$ by mass). These properties result in a significantly larger "apparent solubility" of the target contaminant (equilibrium solubility in an aqueous remediation solution). Hydroxypropyl- $\beta$-cyclodextrin (HPCD) was used at Hill and Dover. Cyclodextrins have many environmental and practical benefits that have been discussed previously (e.g., Brusseau et al. 1994; Wang and Brusseau 1995; McCray and Brusseau 1998, 1999; Wang et al. 1998; Boving and McCray 2000; McCray et al. 2000; Skold et al. 2008). Some of the advantageous attributes of HPCD include: little or no sorption to aquifer solids; does not partition appreciably to the immiscible-phase; can be easily removed from the subsurface after use (minimizing residuals left in situ); does not appreciably reduce the interfacial tension of the aqueous/immiscible-liquid interface (NAPL 
mobilization unlikely); and can be effective at removing metal and organic-metal mixtures.

The University of Arizona (McCray and Brusseau 1998, 1999; Brusseau et al. 1999a; McCray et al. 1999) conducted the field test of cyclodextrin-flushing for cleanup of a contaminated site at Hill AFB. The technology was termed a "Complexing-Sugar Flush" (CSF). The saturated zone within the enclosed cell at Hill AFB was flushed with eight pore volumes of a $10 \mathrm{wt} \%$ HPCD solution. The HPCD solution increased the aqueous concentrations of all the target contaminants to values from about 100 to more than 20,000 times the concentrations obtained during a water flush conducted immediately prior to the CSF. The degree of solubility enhancement was greater for the more-hydrophobic contaminants. Conversely, the relative mass removal was greater for the less-hydrophobic compounds due to their generally higher

(a)
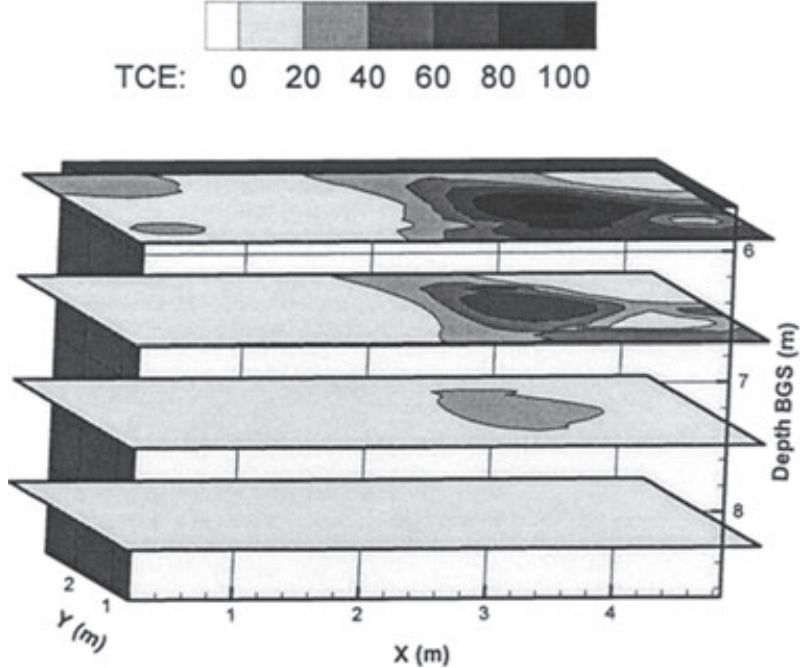

(c)
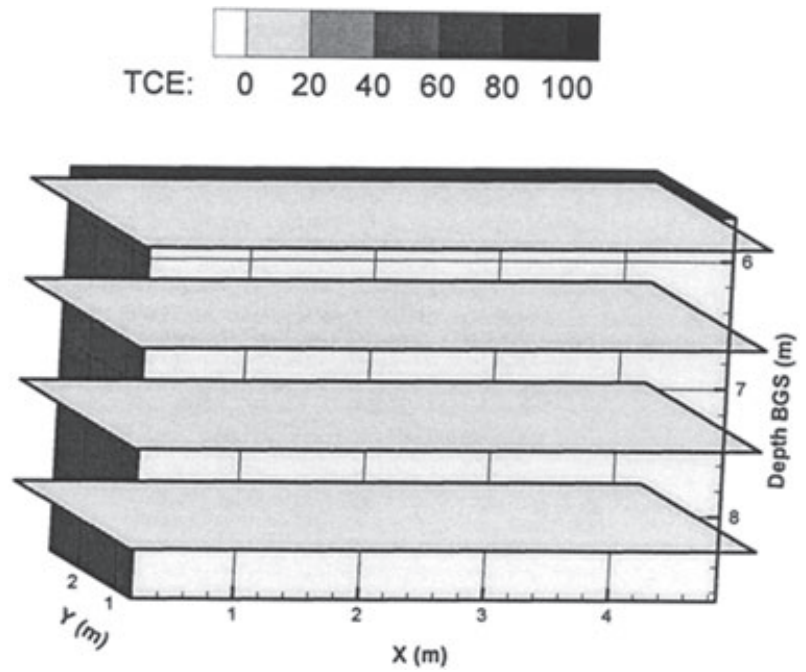

apparent solubilities, which caused a significant reduction in the initial mass during the relatively short experiment. The average reduction in soil-phase concentrations for the target contaminants was $41 \%$, which corresponded well with PTT results (44\% reduction in the average NAPL saturation) (Table 2). The removal was spatially variable and contaminant specific, where some of the more toxic contaminants (e.g., TCE and dichlorobenzene) exhibited more than $90 \%$ removal (Figure 3). This behavior was generally true of all enhanced-solubilization technologies. The successful remediation effort at Hill AFB led to subsequent field applications (Blanford et al. 2001; Tick et al. 2003; Divine et al. 2004; Boving et al. 2008).

At Hill AFB, the NAPL contaminant was a complex mixture of many different contaminants, which is common at many, if not most sites. Thus, the Hill study led to some useful insights regarding dissolution behavior (b)
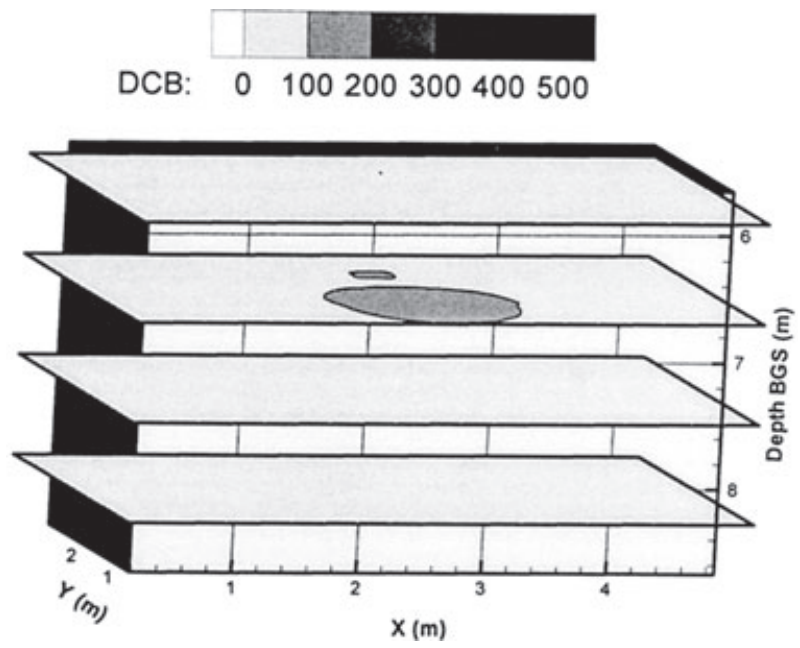

(d)
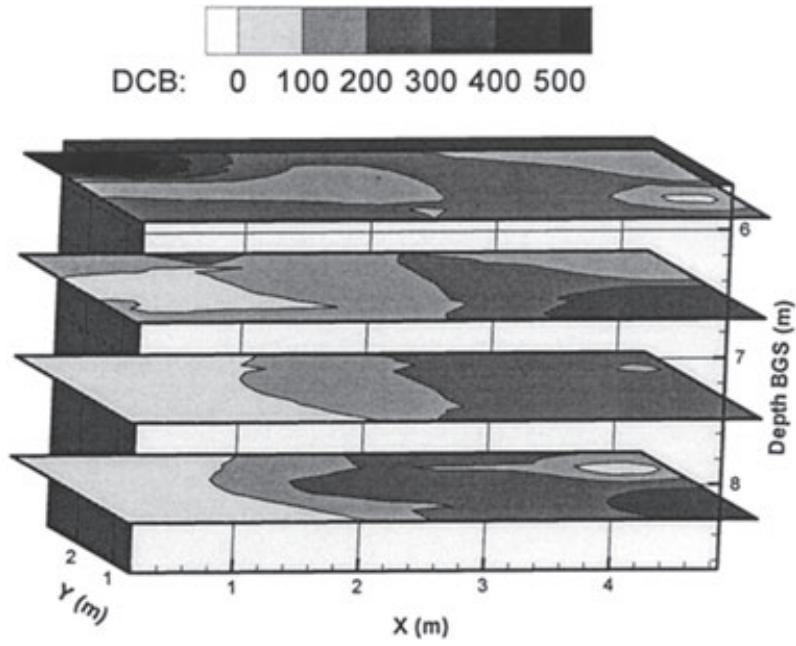

Figure 3. Example of spatial distribution and mass removal in cell 4 at Hill AFB; soil concentrations (mg/kg) (a and b) TCE and DCB before CSF, (c and d) TCE and DCB after CSF. Reprinted in part with permission from McCray and Brusseau (1998). Copyright 1998 American Chemical Society. 
of NAPL mixtures in remediation fluids. The apparent solubility also depends on the NAPL-phase mole fraction, following Raoult's Law. Thus, it is important to recognize that while more-hydrophobic compounds are expected to experience greater solubility enhancements, they may not always experience greater rates of mass removal, which is a direct function of the concentration of the compound in the flushing solution (McCray and Brusseau 1998). An effective analysis of the dissolution behavior required consideration of cyclodextrin-enhanced NAPL-mixture dissolution theory (McCray et al. 1999). NAPL-phase mole fractions could be estimated from soil-core data obtained at the beginning and end of the experiment. For the CSF, the initial peak and final effluent concentrations for most target contaminants were within a factor of two of the equilibrium values predicted using an ideal enhanceddissolution theory. This suggests that the dissolution of the multicomponent NAPL during the cyclodextrin flush may be approximately treated, at least for practical purposes, as an ideal, equilibrium process. Studies by Seo and McCray (2002) demonstrated that the interfacial tension of NAPL mixtures change linearly with mole fraction as a NAPL mixture is dissolved during remediation or dissolution. Interfacial tension is related to NAPL-phase mobility, trapping, and interphase mass transfer. Consideration of NAPL-mixture dissolution dynamics should improve future remediation efforts.

The solubility enhancements during the CSF compared to water-flooding were usually higher than expected based on laboratory experiments (McCray and Brusseau 1998, 1999; Boving et al. 1999; McCray et al. 1999). This may have been due to a reduction in the mass-transfer limitations, potentially by the pore scale effect of increasing NAPL-water interfacial area (McCray and Brusseau 1999). It may have also been due to a somewhat higher viscosity (i.e., a $10 \mathrm{wt} \%$ HPCD solution has a viscosity of $1.153 \mathrm{cp}$ at $22^{\circ}$ (McCray et al. 2000), and HPCD solutions up to $20 \mathrm{wt} \%$ generally had a viscosity within $20 \%$ of that for water (Blanford et al. 2001) that can enable flushing fluids to better access heterogeneous zones that may have been by-passed by the water flushing (e.g., Smith et al. 2008).

Approximately 5 years later Tick et al. (2003) conducted a follow-up field test of cyclodextrin-flushing. The contaminant-release and distribution in cells at the Dover site was described earlier. It was later disclosed that the USEPA researchers released approximately $49 \mathrm{~L}$ of PCE into the test cell, which already contained about $20 \mathrm{~L}$ of PCE from previous technology demonstrations. Based on mass-balance estimates (Tick et al. 2003; Brooks et al. 2004) of the prior water/PTT flush it was determined that there was $68.6 \mathrm{~L}$ in the test cell before the initiation of the cyclodextrin flush. A seven pore-volume water flush was conducted prior to remediation to investigate PCE elution and mass-removal under aqueous flushing (i.e., pump-and-treat).

The configuration of the cyclodextrin flushing experiment consisted of a line-drive flow field (for generalized details on implementation, see the previous discussion on the Dover Test site). The combined extraction effluent was passed through a 7-tray air stripper unit and the off-gas was passed through a series of granular activated carbon reactors to remove remaining PCE and the remaining effluent was directed to the primary cyclodextrin injection tank where it was continuously reinjected into the test cell. Previous experiments indicated that the air stripper was $99.99 \%$ effective at removing PCE from the 15\% cyclodextrin solution (Tick et al. 2003).

The $15 \mathrm{wt} \%$ cyclodextrin solution increased the aqueous concentration of PCE in the extraction-well effluent by a factor of 21.7 times the concentrations obtained during the previous water flush (Figure 4) (Tick et al. 2003), which was essentially identical to the concentration enhancement measured in the laboratory (22.0, by Boving et al. 1999). The 7-pore volume cyclodextrin flushing experiment removed $33 \mathrm{~L}$ of PCE from the subsurface, equivalent to a $48 \%$ mass removal based on the volume of initial PCE present in the test cell prior to the remediation experiment (Table 3). Even with a longer flush, based on tailing of the PCE concentrations (Figure 4), complete PCE mass removal was not expected, likely attributed to zones wherein the PCE was hydraulically inaccessible to the flow regime. Hydraulically inaccessible PCE zones or DNAPL pooling could have resulted during the controlled release process, during the test itself, and/or may have been established from previous experiments conducted in the same test cell (i.e., surfactant flushing and cosolvent flush). A significant increase in fluid viscosity was observed during the $15 \mathrm{wt} \%$ HPCD flushing experiment due to decreased flow rates which had to be adjusted through time until switching back to water near the end of the experiment. Disadvantages include additional power costs or longer residence times of HPCD through the system. However, in some cases higher viscosity flushing solution may be able to invade smaller pore structures that may not be accessible to lower viscosity fluids (e.g., higher mobility ratios, see Smith et al. 2008). In addition, longer residence times may actually be advantageous if mass transfer is rate limited.

At the Dover test site and during other cyclodextrin field experiments, recycling of cyclodextrin from the extracted aqueous phase was shown to be highly successful (Tick et al. 2003; Boving et al. 2007, 2008). Recycling (recovery and reuse) of cyclodextrin did not significantly reduce the effectiveness of the reinjected fluids (Tick et al. 2003; Boving et al. 2007, 2008).

\section{Cosolvent Flood for Enhanced NAPL Solubilization}

The bulk of the light NAPL (LNAPL) material at the Hill site had a low aqueous solubility and vapor pressure. The NAPL solubility was greatly enhanced in alcohol, although it did not fully dissolve in methanol, ethanol, acetone, or isopropanol. The LNAPL did dissolve in higher molecular weight alcohols such as butanols, pentanols, and hexanols. Mixtures of solvents as well as surfactant/cosolvent mixtures were used at Hill and Dover to remove the NAPL by solubilization without inducing mobilization. 

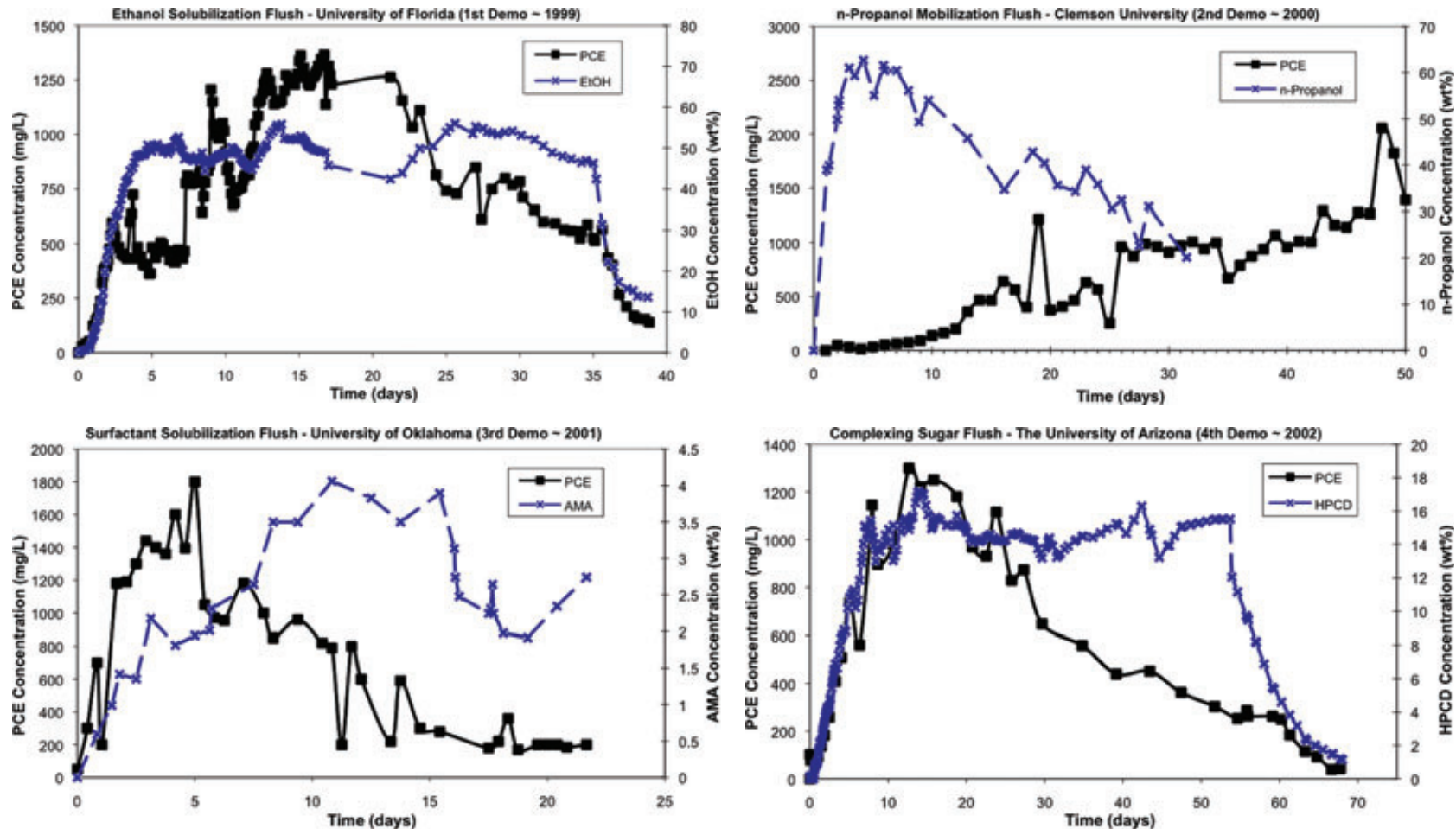

Figure 4. Total combined flux-averaged extraction for PCE and respective flushing agent for Dover AFB demonstrations; (a) cosolvent solubilization demo-UF; (b) cosolvent mobilization demo-CU; (c) surfactant solubilization demo-UO; and (d) CSF-UA.

At Hill AFB, the University of Florida (UF) conducted both an alcohol-water cosolvent flood (Rao et al. 1997) with $70 \%$ ethanol/12\% pentanol/18\% water and a single-phase microemulsion (SPME) flood (Jawitz et al. 1998a) using a mixture of surfactants (polyoxyethylene10-oleyl ether) and alcohol (1-pentanol), which together comprised $5.5 \mathrm{wt} \%$ of the flushing solution. At Dover, UF conducted an alcohol-water cosolvent flood (95\% ethanol) (Brooks et al. 2004). Note that microemulsification, distinct from dissolution, is a dilute dispersion of one phase into another continuous phase. For details on SPME, refer to Rhue et al. (1999) and Jawitz et al. (2001).

At both sites, a significant percentage removal of NAPL was achieved with cosolvent flushing. At Hill, the average mass removal effectiveness as determined from soil coring and partitioning tracers was $87 \%$ and $83 \%$, respectively (Table 2). The NAPL constituent removal effectiveness was greater $(90-99 \%)$ in the upper $1-\mathrm{m}$ zone, in comparison to about $70-80 \%$ in the bottom 0.5 $\mathrm{m}$ zone near the clay confining unit. A lesson learned was that these differences are attributed to inefficiencies in hydrodynamic sweep exacerbated by density gradients between flushing solution and native groundwater. The density gradient that induced gravity override during solvent flooding also resulted in underride of water during the post-remedial water flood (Jawitz et al. 1998b).

At Dover, the amount of NAPL was known (a posteriori) as this was a controlled release blind test. The cosolvent flood removed $64 \%$ of the nonuniformly distributed PCE based on flushing removal (Table 3) (Brooks et al.
2004). For total combined PCE extraction, high removal efficiencies at the end of the test indicated that more PCE could have been removed had it been possible to continue the demonstration (Figure 4). However, PCE removal for individual wells (i.e., upper-zone) proved that either inaccessible mass could not be removed effectively or that all the mass was removed from the upper zone. This is demonstrated by the fact that PCE concentrations declined significantly even though cosolvent concentrations were increasing or stable (Figure 5). A lesson learned from prior studies was the high cost associated with remedial fluids, therefore activated carbon and air stripping treatment were used to recycle the ethanol solution extracted from the cell (Hayden et al. 2001). These combined ex situ treatment systems effectively removed PCE from the effluent, with minimal impact on the ethanol content. Recycling of cosolvent using air stripping and activated carbon treatment was highly effective.

The SPME flood at Hill removed approximately 90 to $95 \%$ of the target NAPL constituents, based on soilcoring analysis, with the residue largely insoluble. The kinetics of the SPME flood were found to be close to equilibrium for all measured constituents of the multicomponent NAPL while the cosolvent dissolution process was increasingly rate-limited as the resulting constituent hydrophobicity increased. The rate limitation for cosolvent dissolution was likely controlled by the rate of diffusion or transport of the component through the organic phase, while the rate-limiting step for microemulsification was independent of the NAPL constituent (or 


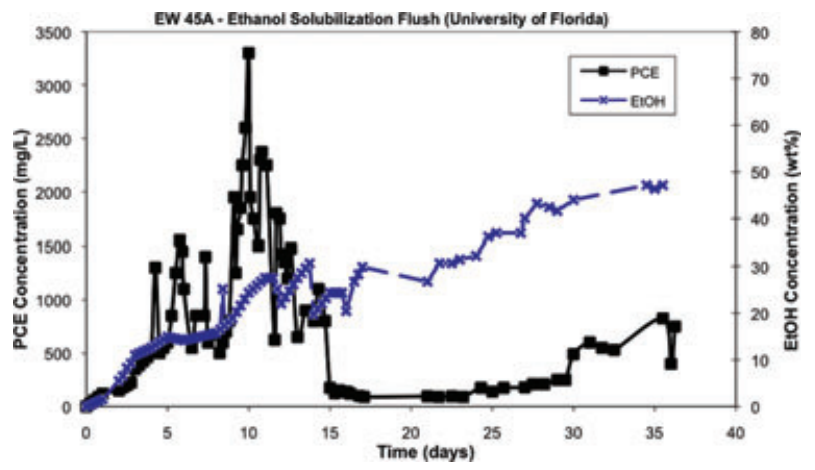

Figure 5. PCE and ethanol concentrations in well 45A (upper zone extraction) during Dover AFB demonstration.

composition) and was likely external to the organic phase. For both studies, laboratory-measured nonequilibrium parameters were used to accurately predict field-scale nonequilibrium NAPL solubilization (Jawitz et al. 2003b). A lesson learned from modeling analyses of both studies was that the effects of field-scale media heterogeneity are likely to dominate those of weakly rate-limited dissolution, and accurate characterization of the former may be sufficient for adequate prediction of field-scale NAPL solubilization.

\section{Cosolvent Flood for NAPL Mobilization}

The cosolvent flood for NAPL mobilization typically uses a mixture of different alcohols that can partition into the NAPL phase, altering its density and lowering interfacial tension, enabling previously immobile NAPL to mobilize as a separate phase toward an extraction well. This greatly enhances NAPL mass recovery.

Clemson University conducted mobilization experiments at Hill and Dover AFB. The Hill experiment consisted of injection and recovery of about four pore volumes of a mixture of $80 \%$ tert-butanol and $15 \% n$ hexanol. Extensive soil coring performed before and after the alcohol flood showed that more than $90 \%$ of the more soluble components of the LNAPL were removed, compared to about 70 to $80 \%$ of the less soluble compounds (Table 2) (Falta et al. 1999a, 1999b). Partitioning interwell tracer tests performed before and after the alcohol flood indicated approximately $80 \%$ bulk removal of LNAPL from the test cell, which was consistent with the soil-core-based mass recovery. A key lesson learned in this test is that complete removal of a complex multicomponent LNAPL from the subsurface by flushing is not likely; however, substantial mass reduction may be achieved.

The density contrast between alcohol and water can lead to gravity override and subsequent alcohol trapping in the capillary fringe. This effect was mitigated during the Dover experiment by dissolving a dense solute in the flooding mixture to give it more neutral buoyancy: $30 \%$ saltwater containing calcium chloride dihydrate was added to water at $175 \mathrm{~g} / \mathrm{L}$ to form a concentrated solution that was mixed with the $n$-propanol. Propanol is a common industrial alcohol with relatively low toxicity and cost. In addition to the increased density of the cosolvent flooding solution, making it easier to deliver to the lower parts of an aquifer, the saltwater also increases the partitioning of propanol into PCE NAPL. In fact, at high cosolvent concentrations, this mixture is capable of converting PCE DNAPL into an LNAPL, thus reducing concerns about NAPL mobilization during the cosolvent flood.

A previous field test of AS in the Dover test cell had involved a controlled release of $66 \mathrm{~L}$ of pure PCE into the test cell by the EPA Project Officer and Staff. The AS experiment removed approximately $58 \mathrm{~L}$ of PCE, leaving about $8 \mathrm{~L}$ of PCE in the test cell (Wood and Enfield 2005). The PCE was released at a depth of $10.7 \mathrm{~m}$, so the experimental treatment zone extended from $10.7 \mathrm{~m}$ down to the confining clay located at a depth of 12-m below ground surface.

Following the PCE release, an initial nonreactive tracer test was performed in the test cell, and it revealed a distinct and isolated high hydraulic conductivity zone near the upper part of the saturated zone. Groundwater samples taken from the extraction wells during this tracer test showed consistently high levels of dissolved PCE, with an average PCE concentration of about $80 \mathrm{mg} / \mathrm{l}$. The individual MLSs showed highly variable dissolved PCE concentrations, ranging from nearly zero, up to the PCE solubility in water (around $200 \mathrm{mg} / \mathrm{l}$ ).

The cosolvent flood operated for a total of 37 days with an average flow rate of about $3.2 \mathrm{~L} / \mathrm{min}$. The initial volume of cosolvent solution on site was about 33,000 L, and the cosolvent was recycled during the experiment by treating it with an air stripper to remove the PCE, so it could be reinjected into the test cell. Maximum extraction well PCE concentrations during the experiment were typically in the range 1000 to $1500 \mathrm{mg} / \mathrm{L}$, or nearly 10 times the normal PCE solubility (Figure 4b). No DNAPL or LNAPL was produced from the extraction wells because the NAPL mobilized in the aquifer was solubilized in the alcohol mix in the extraction well. Over the duration of the field experiment, a total of $45.4 \mathrm{~L}$ of PCE were removed from the test cell (including 1.0 L during the PTT), representing a $78 \%$ removal of the PCE (Table 3 ).

Groundwater sampling was conducted after the conclusion of the cosolvent flooding experiment using the same flow field that was used in the initial nonreactive 
tracer test. Groundwater samples taken from the extraction wells showed lower dissolved PCE concentrations compared to the earlier values, and the average PCE concentration was about $15 \mathrm{mg} / \mathrm{L}$. Therefore, there was approximately an $80 \%$ reduction in the flowing groundwater PCE concentrations measured after the cosolvent flood.

A key lesson learned in these experiments was that NAPL source mass removal results in a corresponding reduction in the average dissolved concentration in the source-zone groundwater. In the Dover experiment, that relationship was linear, because an $80 \%$ reduction in the source mass resulted in an $80 \%$ reduction in the flowing groundwater concentrations. This type of relationship has subsequently been incorporated in mass balance models of coupled source/plume behavior such as REMChlor (Falta 2008). At Hill AFB and Dover AFB, some or most of the remaining contaminant was retained in low hydraulicconductivity sediments and other hydraulically inaccessible zones. Thus, heterogeneity played an important role in the remediation efficiency, even at the intermediate scales of these experiments. The confounding influence of heterogeneity is likely to be even more important at larger scales. It is probably unrealistic to expect complete removal of NAPL using a cosolvent flushing technology; however, it is possible to remove most of the NAPL from the more permeable zones, and it is these zones that contribute the most mass to dissolved plumes.

\section{Surfactants for NAPL Solubilization and Mobilization}

Surfactant enhanced subsurface remediation involves injecting and extracting solutions containing surfactants. The technology takes advantage of several unique characteristics of surfactant molecules. The term "surfactant" comes from the descriptive phrase surf ace active agent. Surfactants are molecules that have both hydrophilic and lipophilic moieties. The amphiphilic nature of surfactant molecules causes them to accumulate at interfaces (e.g., air-water, oil-water, water-solid). This accumulation alters interfacial properties, such as air-water or oil-water interfacial tension. Further, surfactant molecules self-assemble into dynamic aggregates known as micelles once concentrations reach the critical micelle concentration (CMC). The hydrophilic micelle exterior makes them (it) highly soluble in water. Surfactants are classified primarily by their charge (cationic, anionic, nonionic, etc.), as well as by their hydrophilic-lipophilic balance (HLB). Surfactants with a high HLB value are water soluble whereas oil soluble surfactants have a low HLB.

Two different mechanisms are available to remove NAPLs or oils from the subsurface using surfactantssolubilization and mobilization. Surfactant-enhanced "solubilization" results from contaminant partitioning into the oil-like (i.e., hydrophobic or lipophilic) core of the micelle, thereby effectively increasing the aqueous solubility of the contaminant. At low surfactant concentrations (less than the CMC) the contaminant is present at its water solubility. Just above the CMC the solubility enhancement is minor, but increases as the surfactant concentration increases above the CMC. The higher the surfactant concentration is above the $\mathrm{CMC}$, the greater the number of micelles and thus the greater the solubility enhancement of the contaminant.

Surfactant-enhanced "mobilization" refers to bulk displacement of trapped residual NAPL (or pooled NAPL) when the surfactant concentration is below the CMC. Thus, less surfactant mass is required to implement mobilization. The bulk displacement occurs due to reductions in interfacial tension. Significant reductions in the oil-water (i.e., NAPL-water) interfacial tension virtually eliminate the capillary forces that cause the NAPL to be trapped, thereby allowing the oil (NAPL) to readily flush out with the water. Thus, mobilization is maximized when ultra-low interfacial tensions are achieved. The minimum interfacial tension occurs in middle phase microemulsion systems. By adjusting the surfactant system it is possible to transition from normal micelles (aqueous phase, Winsor Type I), to middle phase microemulsions (Winsor Type III), to reverse micelles (oil phase micelles, Winsor Type II).

The University of Oklahoma conducted side-by-side technology demonstrations of both surfactant solubilization and mobilization at Hill and conducted surfactant solubilzation of DNAPL at Dover AFB. In both cases, the surfactant system was tailored to site-specific contaminant and hydrogeology conditions (Sabatini et al. 1999, 2000; Childs et al. 2004; Wood et al. 2005). At Hill AFB, surfactant was injected and extracted using fully screened wells described above in the Hill AFB site description. At Dover AFB, the surfactant system was injected and extracted using vertical-circulation wells. On the basis of soil core analyses, mass removals at Hill AFB were as high as $58 \%$ for solubilization (10 pore volume flush) and in excess of $90 \%$ for mobilization (less than seven pore volume flush) while water flushing alone would have extracted less than $1 \%$ of the LNAPL mass (Knox et al. 1999) (Table 2). At Dover, 65\% mass removal was achieved through solubilization during a 10 pore-volume flush for the DNAPL (Table 3) (Childs et al. 2006). In all cases, groundwater concentrations were reduced by one order of magnitude. Sheet piles introduced artifacts into the demonstration that influenced the effectiveness: they artificially minimized dilution of the extracted surfactant solutions; and small leaks along joints in the sheet piling prevented complete flushing of the surfactant solubilization cell. At both sites, recovery of the surfactant solutions was high (95\%), but may have been influenced by the sheet piles.

Soil cores, PTTs, and groundwater concentrations provided different measures of mass-removal effectiveness. Advantages and disadvantages are associated with each method. For example, the partitioning alcohols may have partitioned into the residual surfactant left in the cell, which resulted in negative removal versus $>90 \%$ from pre and post soil cores. For a detailed discussion on advantage and disadvantages of these methods, the reader is referred to Wood and Enfield (1999). 
Surfactant solubilization is a robust technology that is easier to design and implement than surfactant mobilization. However, surfactant mobilization is much more efficient than solubilization and should be utilized if vertical migration of the mobilized contaminant is not of concern or when it is accounted for in the designs of the surfactant solution and injection/extraction system. For large scale applications $\left(>500 \mathrm{~m}^{2}\right.$ ) surfactant flushing is most economical at ultralow surfactant concentrations, which implies use of the mobilization technology. The surfactant mobilization solution is more viscous than the native groundwater and it influences flow mechanics in the subsurface (e.g., mounding) and should be accounted for in design of injection/extraction systems. Subsurface heterogeneities place a fundamental limit on the level of remediation achievable by flushing technologies. Because of field-scale heterogeneities a uniform flush of subsurface cannot be achieved, and thus uniform contaminant removal cannot be achieved (Figure 4). Surfactant-based flushing can dramatically reduce contaminant flux from a target zone, but it cannot return the subsurface to pristine conditions.

\section{Partitioning-Tracer and BioTracer Tests}

PTTs are one of the few methods available for characterizing the occurrence, quantity, and distribution of organic liquids in subsurface environments. Several pilot-scale PTTs were conducted as part of the Hill AFB remediation studies (e.g., Rao et al. 1997; Annable et al. 1998a, 1998b; Jawitz et al. 1998a; McCray and Brusseau 1998; Falta et al. 1999a, 1999b; Cain et al. 2000). These pilot-scale tests constituted some of the initial applications of the PTT method for environmental systems. PTTs have several advantages compared to traditional methods such as soil-coring or groundwater sampling. In particular, the PTT evaluates the entire zone swept by the remediation fluids, and provides a bulk mass/volume estimate that is relevant for the scale of remediation. Soil cores and aqueous samples represent only a very small fraction of the remediated zone (i.e., less than $1 \%$ of the total volume). However, PTTs cannot provide a detailed spatial distribution of the contamination, and do not provide information on individual contaminants. In addition, Divine et al. (2004) suggested that NAPL saturations greater than a threshold value (e.g., $0.1 \%$ ) may be required for the PTT to be able to accurately measure NAPL saturation with typical partitioning tracers, to enable sufficient separation of breakthrough curves from field data (required to calculate retardation coefficients used to obtain saturations). However, this concept is not relevant for the Hill and Dover sites because pre- and post-remediation NAPL saturations were higher.

Cain et al. (2000) evaluated the performance of the PTT method by comparing results obtained with the PTT to measurements of organic-liquid mass and mass removal obtained from analyses of sediment-core data. A reduction in immiscible-liquid saturation of $44 \%$ was calculated based on the results of the PTTs conducted before and after the CSF, which compares very well to the weightedmean mass removal value of $41 \%$ determined from soilcore data collected for 12 constituents (Table 1). These and similar results obtained for most of the other studies at Hill AFB indicated that the PTT method provided robust measures of organic-liquid contamination under the prevailing conditions. PTTs were also conducted as part of the Dover AFB remediation studies. Brooks et al. (2002) evaluated PTT performance for a case wherein the volume of organic liquid present was known due to its having been emplaced prior to the start of the study. In this case, the PTT method produced underestimates of the organic liquid, perhaps in part because of the relatively small volume present.

When applying PTTs with enhanced chemical agents, particularly those that rely on a partitioning concept, care must be taken to determine if the remediation agent influences the partitioning coefficient of one or more target analytes. For example, cyclodextrin and ethanol influenced the value of PTT partitioning coefficients between $0 \%$ and $50 \%$, depending on the contaminant (Dugan et al. 2003; Cho et al. 2003). Dugan et al. (2003) hypothesized that the cyclodextrin effect may have resulted from the alcohol-based tracers partitioning inside the HPCD cavity, or complexing with the hydroxyl-propyl groups, thus inhibiting tracer partitioning to the NAPL. Ethanol likely reduces the strength of partitioning because the alcohol-based tracers would have a stronger affinity to remain in the aqueous phase. Surfactants sorbed to aquifer materials have been shown to produce partitioning tracer retardation that indicates a false NAPL saturation of up to 0.23 (Cho et al. 2004). These potential impacts should be considered in the design of the PTT. The popularity of in situ bioremediation as a preferred method for cleaning up contaminated sites has greatly increased interest in the biodegradation of organic compounds in the subsurface. This interest has been compounded by the consideration of natural attenuation via intrinsic bioremediation as a cleanup alternative. Evaluating the feasibility of biotransformation-based methods for a specific site requires a determination of the in situ biodegradation potential of the target contaminants in the contaminated zone.

Biotracer tests are one method to characterize in situ biodegradation potential (Istok et al. 1997; Brusseau et al. 1999b). Some of the first field-scale biotracer tests were conducted at Hill AFB as part of the remediation studies. Alter et al. (2003) conducted biotracer tests to evaluate the effect of the CSF on in-situ biodegradation potential. The results indicated that the CSF did not deleteriously influence the indigenous microbial community, but rather, appeared to enhance activity. Sandrin et al. (2004) used the results of biotracer tests to characterize the spatial distribution of microbial activity and the impact of residence time on biodegradation-induced mass loss.

PTT higher moments can be used to ascertain information about the spatial distribution of NAPL within the swept volume, even with only one monitoring location. Jawitz et al. (2003a) used PTT higher-moment analysis 
combined with a streamtube approach for this purpose. The proportion of streamtubes that contain NAPL (versus those that are uncontaminated) can be determined, as can the variance of the distribution of NAPL saturations between the streamtubes. The authors concluded that the all of the streamtubes in the swept volume were contaminated, and that there was little variation in the NAPL saturation between the streamtubes. Similarly, using PTT data from a DNAPL site, these authors found that approximately two-thirds of the streamtubes contained NAPL. These results were consistent with soil core data from both sites.

\section{General Discussion on Mass Removal and Mass Flux Reduction}

Each pilot-scale field experiment was configured differently, according to goals of each research group and "best" contaminant removal scenarios. For example, design configurations included line-drive flow fields initiating horizontal flow through the system, five-spot and double five-spot flow fields targeting specific regions within the test cells, and vertical recirculation to enhance removal through low hydraulic conductivity regions. However, essentially all remediation demonstrations utilized similar flushing principles to remove as much contamination from the assigned test cell as possible. At both Dover and Hill AFB, the specific results from these remediation demonstrations showed that there was a significant increase in contaminant mass removal compared to water flushing (i.e., pump and treat) alone. At the Dover Test Site, because predetermined amounts of PCE were released before each demonstration, mass balances and contaminant percent recoveries could be assessed to a higher degree of accuracy.

In terms of full-scale remediation operation, these results further support expected difficulties in removing all of the immiscible-liquid contaminant mass from the system in desired time scales even from relatively homogeneous conditions with constrained fluid flow regimes due to the test cells (which limited larger-scale bypass flow). At Dover, the NAPL was emplaced and thus dissolved PCE was not as likely to reside in clay and other immobile water zones where removal by engineered methods is more difficult. Immiscible-liquid contaminant mass removal and percent recovery are expected to be lower in more heterogeneous unconstrained systems. For the most part, the incomplete mass removal of immiscible liquid PCE in the Dover pilot-scale demonstrations was attributed to hydraulically inaccessible zones of immiscible liquid (Figures 4 and 5). The PCE distribution was controlled by vertical heterogeneities, while flushing effectiveness is limited by both vertical and horizontal heterogeneities. Limited effectiveness may also have resulted from pooling of immiscible liquid PCE in the test cell. In some of the enhanced-flushing demonstrations, the flow regimes and pumping scenarios were altered or modified to test whether PCE removal rates could be improved (Brooks et al. 2004; Childs et al. 2006). The results are inconsistent in that some of these modified configurations did improve contaminant removal while others were unsuccessful. These results may suggest that further testing of pumping patterns and pumping schedules are needed to fully understand which systems are optimal for contaminant removal. Results from a field experiment by Boving et al. (2008) suggested that "pushpull" delivery/extraction of the remediation fluid may be more effective for source zones because they help overcome heterogeneities and can also reduce waste that must be treated or disposed.

As mentioned previously, significant mass removal of NAPL was achieved during all enhanced-flushing demonstrations, exhibited by the considerable increase in the apparent solubility of target contaminants during enhanced flushing compared to water-only flushing. Interestingly, at Dover, regardless of specific flushing agent, similar enhancement factors of PCE were observed for all enhanced-flushing demonstrations ranging between 20 and 30. Enhancement factors are determined by calculating the ratio of the peak PCE concentration obtained during the enhanced-flushing experiment compared to the average PCE concentration during water flushing conditions alone.

The magnitude of the reduction in contaminant mass flux obtained for a specific depletion of source-zone mass is a key consideration for evaluating the effectiveness of a source-zone remediation effort. Thus, there is great interest in characterizing, estimating, and predicting relationships between mass flux reduction and mass removal. The remediation pilot studies conducted at Hill AFB provided data for some of the initial field-scale analyses of the impact of source-zone mass reduction on mass flux. For these studies, initial and final immiscible-liquid masses in the test cell were obtained from sediment-core and PTT data, thus allowing calculation of mass reductions. Reductions in aqueous-phase concentrations (equitable to mass flux) were based on collection of groundwater samples before and after remediation from MLS points located within the cell. The aqueous concentrations were up to an order of magnitude lower after the remediation test (Rao et al. 1997; Brusseau et al. 1999a). DiFilippo and Brusseau (2008) and Jawitz et al. (2005) calculated composite mass-flux-reduction/mass-removal values for these tests. For the cosolvent test conducted by Rao et al. (1997), a composite reduction in aqueous concentrations of 0.84 was associated with a composite mass reduction of 0.9 for the four target analytes monitored. For the CSF test conducted by McCray and Brusseau (1998, 1999) and Brusseau et al. (1999a), a composite reduction in aqueous concentrations of 0.9 was associated with a composite mass reduction of 0.75 for the 10 target analytes monitored. Reductions in mass flux associated with source-zone mass reduction were reported for several of the remediation pilot studies conducted at Dover AFB. Mass reductions were calculated using PTT data, and mass flux reductions were calculated using data collected from extraction wells. Mass-flux-reduction/mass-removal values of $0.5 / 0.64,0.8 / 0.8$, and $0.9 / 0.64$ were obtained for the ethanol-cosolvent (Brooks et al. 2004), propanolcosolvent (Falta et al. 2005b), and surfactant (Childs et al. 
2006) tests, respectively. Nearly 1:1 correlation existed between NAPL mass removal and average dissolved PCE concentrations in the groundwater. A simple mass balance approach with this relationship predicts that the NAPL recovery during flushing will decline exponentially with time (e.g., Chen and Jawitz 2009). Moreover, an exponential decline of both DNAPL mass and mass discharge to the plume with time is expected under natural dissolution conditions.

\section{Summary of Most Important Lessons Learned}

A summary of the lessons learned from experiments and data analysis completed at the Hill and Dover sites is provided below.

- All enhanced-flushing demonstrations showed similar remediation effectiveness for 5 to 10 pore-volume flushes. At Dover AFB, mass removal varied between $50 \%$ and $98 \%$, and at Hill AFB, $41 \%$ to $97 \%$ removal was demonstrated. Consistent results were achieved probably because each technology was implemented by expert teams with the freedom to optimize remediation as they deemed appropriate. This demonstrates the value of technology-specific expertise, and tailoring remediation to site and contaminant conditions.

- The studies elucidated the importance of even smallscale heterogeneities on remediation effectiveness, and thus fomented the recent flurry of research funded by $\mathrm{DoD}$ on enhanced-delivery methods. A particularly important hypothesis that was developed based on these studies was that most removal occurs in high hydraulic conductivity zones (where most of the contaminant resides), yet complete removal, and thus long term site cleanup, is limited by contaminant mass stored in low hydraulic conductivity zones or isolated in hydraulically inaccessible regions (i.e., flow field specific). It was demonstrated that even in the relatively homogeneous systems represented by Hill and Dover tests sites that significant contaminant mass may be hydraulically inaccessible likely due to small variations in flow field. Push-pull remediation schemes implemented in heterogeneous zones may be helpful to overcome the influence of heterogeneities (e.g., Boving et al. 2008).

- These studies supported the hypothesis that complete mass recovery is not likely to be achieved with these technologies. However, groundwater concentrations were generally reduced by one order of magnitude, and mass fluxes leaving source zones were significantly reduced (McCray et al. 1999; Wood et al. 2005; Tick et al. 2003; DiFilippo and Brusseau 2008; Jawitz et al. 2005). This led to debate and ongoing research on partial source-zone removal. Data from these and subsequent studies show that reduction in groundwater concentrations and mass flux are highly correlated to source-zone NAPL removal and that alternative methods such as mass flux reduction may be more appropriate for evaluating risk assessment rather than relying on point concentration reductions.
- The effectiveness of characterization methods (PTTs, soil cores, groundwater sampling) are somewhat site specific (e.g., Brusseau et al. 1999a; Jawitz et al. 2003b), and possibly even technology specific (e.g., Dugan et al. 2003), and thus are not highly reliable for assessing remediation effectiveness by themselves. However, using multiple methods, each of which may give a different removal assessment, enables the user to better quantify the uncertainty associated with the mass estimates. Soil cores and groundwater sampling, even when collected at high densities, were not as robust as predicted for understanding the spatial distribution and removal of NAPL.

- Success in isolated test cells at Hill and Dover led to successful implementation in unbounded (no sheet pile) DNAPL sites (Jawitz et al. 2000; Divine et al. 2004; Boving et al. 2008). Thus, there is considerable benefit in conducting smaller scale pilot tests with regard to cleanup effectiveness, even though this approach adds additional cost to the front end of long-term projects.

- During these studies, we discovered the importance of understanding the fluid dynamics and interfacial behavior of injected remediation fluids on remediation design and implementation (density differences in fluids, viscosity effects, and changes in interfacial tension) (Jawitz et al. 1998b; Falta et al. 1999a; Seo and McCray 2002; Tick et al. 2003; Childs et al. 2006). For example, the studies led to considerable improvements in application of multiphase-fluid and mobilization technologies, which can be highly effective even for a few flushed pore volumes, but requires careful design to minimize bypass flow due to multiphase fluid movement. In addition, alteration of interfacial properties can influence NAPL-aqueous mass-transfer constraints for enhanced-solubilization technologies.

- The success and feasibility of implementing enhanced flushing under full-scale operation is highly dependent upon the ability to reuse and recycle the flushing reagent to lower costs and improve overall efficiency. All of the enhanced flushing demonstrations showed that recycling and reuse could be successfully implemented, improving flushing efficiency and decreasing associated costs of remediation (e.g., Knox et al. 1999; Tick et al. 2003; Brooks et al. 2004; Boving et al. 2007). However, in some cases flushing agent should be sequentially added to the flushing solution to maintain an effective enhanced-solubilization performance associated with volatilization/evaporation of the flushing solution during the remediation and treatment process.

- Solubilization is a robust technology that is easier to design and implement than mobilization, and poses less risks due to the potential for vertical NAPL migration. While mobilization has the potential to be much more effective than solubilization, the risks stated above must be balanced with this increased effectiveness (Falta et al. 1999a; Knox et al. 1999; Sabatini et al. 1999) which has led to novel implementation methods such as 
supersolubilization and gradient technologies (Sabatini et al. 2000).

- At most sites, the NAPL is a complex mixture of many different contaminants. An effective analysis of the dissolution behavior requires consideration of NAPL-mixture dissolution theory (Gierke et al. 1999a; McCray and Brusseau 1999; McCray and Dugan 2002; Jawitz et al. 2003b). This analysis will lead to a better understanding of remediation processes, which should improve future remediation efforts.

- These studies showed the benefits of using tracer tests to assess NAPL distribution, and not just the NAPL mass or volume (Jawitz et al. 2003a, 2000b).

- Field-scale applications often resulted in significantly different values for equilibrium and kinetic model masstransfer parameters compared to those measured in the laboratory, emphasizing the importance of considering the field-scale influences of heterogeneities and NAPL architecture on the apparent mass-transfer behavior of the larger scale (McCray and Brusseau 1999; McCray et al. 2000; Heron et al. 2002; Jawitz et al. 2003b; van Antwerp et al. 2008).

- The results from this study helped researchers better understand what processes and scales are most important to include in mathematical models used for design and data analysis (Hein et al. 1997; Jawitz et al. 2003a, 2005; Divine et al. 2004; Falta et al. 2005a).

\section{Acknowledgments}

All contributors to this research are too numerous to name here. Dr. Carl Enfield of U.S. EPA, Dr. Suresh Rao of Purdue University, and Dr. Philip Bedient of Rice University were instrumental to the design and completion of this research. The research could not have been completed without the hard work of undergraduate and graduate students, and faculty and staff at the authors' institutions. Many of the contributors' names appear on publications cited in this article. The original field research was funded by the U.S. Department of Defense, via the U.S. EPA. Dr. Walter Illman at the University of Waterloo, and two anonymous reviewers, provided helpful and insightful comments to this manuscript, greatly improving its quality.

\section{References}

Alter, S.R., M.L. Brusseau, J.J. Piatt, A. Ray-Maitra, J.-M. Wang, and R.B. Cain. 2003. Use of tracer tests to evaluate the impact of enhanced-solubilization flushing on in-situ biodegradation. Journal of Contaminant Hydrology 64, no. 3-4: 191-202.

Annable, M.D., P.S.C. Rao, K. Hatfield, W.D. Graham, A.L. Wood, and C.G. Enfield. 1998a. Partitioning tracers for measuring residual NAPL: Field-scale results. Journal of Environment Engineering 124, no. 6: 498-503.

Annable, M.D., J.W. Jawitz, P.S.C. Rao, D.P. Dai, H. Kim, and A.L. Wood. 1998b. Field evaluation of interfacial and partitioning tracers for characterization of effective NAPLwater contact areas. Ground Water 36, no. 3: 495-502.
Bedient, P.B., A.W. Holder, C.G. Enfield, and A.L. Wood. 1999. In Enhanced Remediation Demonstrations at Hill Air Force Base: Introduction. Innovative Subsurface Remediation: Field Testing of Physical, Chemical, and Characterization Technologies, ed. M.L. Brusseau, D.A. Sabatini, J.S. Gierke, and M.D. Annable, 36-48. ACS Symposium Series. Washington, DC: American Chemical Society.

Blanford, W.J., M.L. Barackman, T.B. Boving, E.J. Klingel, G.R. Johnson, and M.L. Brusseau. 2001. Cyclodextrinenhanced vertical flushing of a trichloroethene contaminated aquifer. Ground Water Monitoring \& Remediation 21, no. 1: 58-66.

Boving, T.B., and J.E. McCray. 2000. Cyclodextrin-enhanced remediation of organic and metal contaminants in porous media and groundwater. Remediation Journal 10, no. 2: $59-83$.

Boving, T.B., X. Wang, and M.L. Brusseau. 1999. Cyclodextrinenhanced solubilization and removal of residual chlorinated solvents from porous media. Environmental Science \& Technology 33, no. 5: 764-770.

Boving, T.B., S.M. Barnett, G. Perez, W.J. Blanford, and J.E. McCray. 2007. Remediation with cyclodextrin: Recovery of the remedial agent by membrane filtration. Remediation Journal 17, no. 3: 21-36.

Boving, T.B., W.J. Blanford, J.E. McCray, C.E. Brusseau, and M.L. Divine. 2008. Comparison of line-drive and push-pull flushing schemes. Ground Water Monitoring \& Remediation 28, no. 1: 75-86.

Brooks, M.C., M.D. Annable, P.S.C. Rao, K. Hatfield, J.W. Jawitz, W.R. Wise, A.L. Wood, and C.G. Enfield. 2002. Controlled release, blind tests of DNAPL characterization using partitioning tracers. Journal of Contaminant Hydrology 59, no. 1-2: 187-210.

Brooks, M.C., M.D. Annable, P.S.C. Rao, K. Hatfield, J.W. Jawitz, R. William, W.R. Wise, A.L. Wood, and C.G. Enfield. 2004. Controlled release, blind test of DNAPL remediation by ethanol flushing. Journal of Contaminant Hydrology 69, no. 1-2: 281-297.

Brusseau, M.L., X. Wang, and Q. Hu. 1994. Enhanced transport of low-polarity organic compounds through soil by cyclodextrin. Environmental Science \& Technology 28, no. 5: 952-956.

Brusseau, M.L., J.E. McCray, G.R. Johnson, X. Wang, A.L. Wood, and C. Enfield. 1999a. Field test of cyclodextrin for enhanced in-situ flushing of multiple-component immiscible organic liquid contamination: Project overview and initial results. In Innovative Subsurface Remediation: Field Testing of Physical, Chemical and Characterization Technologies, ed. M.L. Brusseau, D.A. Sabatini, J.S. Gierke, and M.D. Annable, 118-135. ACS Symposium Series. Washington, DC: American Chemical Society.

Brusseau, M., J. Piatt, J. Wang, and M. Hu. 1999b. A biotracer test for characterizing the in-situ biodegradation potential associated with subsurface systems. In Innovative Subsurface Remediation, Field Testing of Physical, Chemical, and Characterization Technologies, ed. M. Brusseau, D. Sabatini, J. Gierke, and M. Annable, 240-250. Washington, DC: American Chemical Society.

Cain, R.B., G.R. Johnson, J.E. McCray, W.J. Blanford, and M.L. Brusseau. 2000. Partitioning tracer tests for evaluating remediation performance. Ground Water 38, no. 5: $752-761$.

Castor, M.G. 2002. Ozone-enhanced air sparging of trichloroethlyene in a pilot-scale aquifer. M.S. Thesis, Department of Geological \& Mining Engineering \& Sciences, Michigan Technological University, Houghton, Michigan.

Chen, X., and J.W. Jawitz. 2009. Convergence of DNAPL source strength functions with site age. Environmental Science \& Technology 43, no. 24: 9374-9379.

Childs, J., E. Acosta, M.D. Annable, M.C. Brooks, C.G. Enfield, J.H. Harwell, M. Hasegawa, R.C. Knox, P.S.C. Rao, D.A. 
Sabatini, B. Shiau, E. Szekers, and A.L. Wood. 2006. Field demonstration of surfactant-enhanced solubilization of DNAPL at Dover Air Force Base, Delaware. Journal of Contaminant Hydrology 82, no. 1-2: 1-22.

Childs, J.D., E. Acosta, R.C. Knox, J.H. Harwell, and D.A. Sabatini. 2004. Improving the extraction of tetrachloroethylene from soil columns using surfactant gradient systems. Journal of Contaminant Hydrology 71, no. 1-2: 27-45.

Cho, J., M.D. Annable, and P.S.C. Rao. 2003. Residual alcohol influence on NAPL saturation estimates based on partitioning tracers. Environmental Science \& Technology 37, no. 8: $1639-1644$

Cho, J., M.D. Annable, and P.S.C. Rao. 2004. Influence of residual surfactants on DNAPL characterization using partitioning tracers technique. Journal of Contaminant Hydrology 72, no. 1-2: 67-83.

DiFilippo, E.L., and M.L. Brusseau. 2008. Relationship between mass flux reduction and source-zone mass removal: Analysis of field data. Journal of Contaminant Hydrology 98, no. $1-2$ : 22-35.

Divine, C.E., J.E. McCray, T. Boving, D. Blitzer, L. Wolf Martin, M.L. Brusseau, and W. Blanford. 2004. Partitioning tracer tests as remediation metric: Case study at naval amphibious base little creek (NABLC), Virginia. Remediation Journal 14, no. 2: 7-31.

Dugan, P.J., J.E. McCray, and G.D. Thyne. 2003. Influence of cyclodextrin on NAPL-water partition coefficients with implications for post-remediation NAPL characterization using partitioning tracer tests. Water Resources Research 39, no. 5: $1.1-1.7$

Falta, R.W. 2008. Methodology for comparing source and plume remediation alternatives. Ground Water 46, no. 2: 272-285.

Falta, R.W., C.M. Lee, S.E. Brame, E. Roeder, L. Wood, and C. Enfield. 1999a. In Innovative Subsurface Remediation: Field Testing of Physical, Chemical, and Characterization Technologies, Brusseau (Chapter 8), ed. M.L. Sabatini, D. Gierke, and J. Annable, 102-117. Washington DC: American Chemical Society.

Falta, R.W., C.M. Lee, S.E. Brame, E. Roeder, J.T. Coates, C. Wright, A.L. Wood, and C.G. Enfield. 1999b. Field test of high molecular weight alcohol flushing for subsurface nonaqueous phase liquid remediation. Water Resources Research 35, no. 7: 2095-2108.

Falta, R.W., P.S.C. Rao, and N. Basu. 2005a. Assessing the impacts of partial mass depletion on DNAPL source-zones: I. Analytical modeling of source strength functions and plume response. Journal of Contaminant Hydrology 78, no. 4: 259-208.

Falta, R.W., N. Basu, and P.S.C. Rao. 2005b. Assessing the impacts of partial mass depletion on DNAPL source-zones: II. Coupling source strength functions to plume evolution. Journal of Contaminant Hydrology 79, no. 1-2: 45-66.

Gierke, J.S., C.L. Wojick, and N.J. Hutzler. 1999a. Field test of air sparging coupled with soil vapor extraction. In Innovative Subsurface Remediation, Field Testing of Physical, Chemical, and Characterization Technologies, ed. M. Brusseau, D. Sabatini, J. Gierke, and M. Annable, 153-166. Washington, DC: American Chemical Society.

Gierke, J.S., D.L. Sanders, and D.L. Perram. 1999b. Laboratory studies of aqueous partitioning tracer tests for measuring nonaqueous phase liquid volumes. Water Environment Research 71, no. 4: 465-474.

Gierke, J.S. 2000. Conventional vapor extraction, Section 7.2.1. In Remediation of Organic Chemicals in the Vadose Zone, Chapter 7 by L. Murdoch, in Vadose Zone Science and Technology Solutions, ed. B.B. Looney, and R.W. Falta, vol. II: 951-969. Columbus, OH: Battelle Press.

Hayden, N.J., M.C. Brooks, M.D. Annable, and H. Zhou. 2001. Alcohol recovery from alcohol/chlorinated solvent mixtures using activated carbon. Journal of Environmental Engineering 127, no. 12: 1116-1123.
Hein, G.L., J.S. Gierke, N.J. Hutzler, and R.W. Falta. 1997. Three-dimensional experimental testing of a two-phase flow-modeling approach for air sparging. Ground Water Monitoring \& Remediation 17, no. 3: 222-230.

Heron, G., J.S. Gierke, B. Faulkner, S. Mravik, A.L. Wood, and C.G. Enfield. 2002. Pulsed air sparging in aquifers contaminated with dense non-aqueous phase liquids. Ground Water Monitoring \& Remediation 22, no. 4: 73-82.

Istok, J.D., M.D. Humphrey, M.H. Schroth, M.R. Hyman, and K.T. O'Reilly. 1997. Single-well, "push-pull" test for insitu determination of microbial activities. Ground Water 35 , no. 3: 619-631.

Jawitz, J.W., M.D. Annable, P.S.C. Rao, and R.D. Rhue. 1998a. Field implementation of a winsor type i surfactant/alcohol mixture for in situ solubilization of a complex LNAPL as a single-phase microemulsion. Environmental Science \& Technology 32, no. 4: 523-530.

Jawitz, J.W., M.D. Annable, and P.S.C. Rao. 1998b. Miscible fluid displacement stability in unconfined porous media: Two-dimensional flow experiments and simulations. Journal of Contaminant Hydrology 31, no. 1-2: 211-230.

Jawitz, J.W., R.K. Sillan, M.D. Annable, P.S.C. Rao, and K. Warner. 2000. In situ alcohol flushing of a DNAPL source zone at a dry cleaner site. Environmental Science \& Technology 34, no. 17: 3722-3729.

Jawitz, J.W., M.D. Annable, P.S.C. Rao, and R.D. Rhue. 2001. Evaluation of remediation performance and cost for field-scale single-phase microemulsion (SPME) flushing. Journal of Environmental Science and Health Part A-Toxic/Hazardous Substances \& Environmental Engineering 36, no. 1: 1437-1450.

Jawitz, J.W., M.D. Annable, G.G. Demmy, and P.S.C. Rao. 2003a. Estimating nonaqueous phase liquid spatial variability using partitioning tracer higher temporal moments. Water Resources Research 39, no. 7: SBH7.1-SBH7.19.

Jawitz, J.W., D.P. Dai, P.S.C. Rao, M.D. Annable, and R.D. Rhue. 2003b. Rate-limited solubilization of multicomponent nonaqueous-phase liquids by flushing with cosolvents and surfactants: Modeling data from laboratory and field experiments. Environmental Science \& Technology 37, no. 9: 1983-1991.

Jawitz, J.W., A.D. Fure, G.G. Demmy, S. Berglund, and P.S.C. Rao. 2005. Groundwater contaminant flux reduction resulting from nonaqueous phase liquid mass reduction. Water Resources Research 41, no. 10: 1-15.

Knox, R.C., B.J. Shau, D.A. Sabatini, and J.H. Harwell. 1999. In Field Demonstration Studies of Surfactant-Enhanced Solubilization and Mobilization at Hill Air Force Base, Utah. Innovative Subsurface Remediation: Field Testing of Physical, Chemical, and Characterization Technologies, ed. M.L. Brusseau, D.A. Sabatini J.S. Gierke, M.D. Annable, and A.C.S. Symposium Series, 49-63. Washington, DC: American Chemical Society.

McCray, J.E., and M.L. Brusseau. 1998. Cyclodextrin-enhanced in-situ flushing of multiple-component immiscible organicliquid contamination at the field scale: Mass removal effectiveness. Environmental Science \& Technology 32, no. 9: $1285-1293$.

McCray, J.E., and M.L. Brusseau. 1999. Cyclodextrin-enhanced in situ flushing of multiple-component immiscible organicliquid contamination at the field scale: Analysis of dissolution behavior. Environmental Science \& Technology 33, no. 1: 89-95.

McCray, J.E., K. Bryan, R. Cain, G. Johnson, B. Blanford, and M.L. Brusseau. 1999. Field test of cyclodextrin for enhanced in-situ flushing of immiscible organic liquids: Comparison to water flushing. In: Innovative Subsurface Remediation: Field Testing of Physical, Chemical, and Characterization Technologies, 136-152. Washington, DC: American Chemical Society. 
McCray, J.E., T. Boving, and M.L. Brusseau. 2000. Enhanced dissolution of hydrophobic organic compounds with implications for aquifer remediation. Ground Water Monitoring \& Remediation 20, no. 1: 94-103.

McCray, J.E. 2000. Mathematical modeling of air sparging for subsurface remediation: State of the art. Journal of Hazardous Materials 72, no. 2-3: 237-263.

McCray, J.E., and P.J. Dugan. 2002. Nonideal equilibrium dissolution of trichloroethene from a decane-based NAPL mixture: Experimental and modeling investigation. Water Resources Research 38, no. 7: 2.1-2.9.

McCray, J.E., and R.W. Falta. 1997. Numerical simulation of air sparging for remediation of NAPL contamination. Ground Water 35, no. 1: 99-110.

National Research Council (NRC) (U.S.). 1999. Groundwater and Soil Cleanup: Improving Management of Persistent Contaminants. Washington, DC: National Academy of Sciences.

National Research Council (NRC) (U.S.). 2000. Research Needs in Subsurface Science. Washington, DC: National Academy of Sciences.

National Research Council (NRC) (U.S.). 2005. Contaminants in the Subsurface: Source Zone Assessment and Remediation. Washington, DC: National Academy of Sciences.

Rao, P.S.C., M.D. Annable, R.K. Sillan, D. Dai, K. Hatfield, W.D. Graham, A.L. Wood, and C.G. Enfield. 1997. Fieldscale evaluation of in situ cosolvent flushing for enhanced aquifer remediation. Water Resources Research 33, no. 12: 2673-2686.

Rhue, R.D., P.S.C. Rao, and M.D. Annable. 1999. Singlephase microemulsification of a complex light nonaqueous phase liquid: laboratory evaluation of several mixtures of surfactant/alcohol solutions. Journal of Environmental Quality 28, no. 4: 1135-1144.

Sabatini, D.A., J.H. Harwell, and R.C. Knox. 1999. Surfactant selection criteria for enhanced subsurface remediation. In Innovative Subsurface Remediation: Field Testing of Physical, Chemical and Characterization Technologies, ed. M.L. Brusseau, D.A. Sabatini, J.S. Gierke, and M.D. Annable, 8-23. ACS Symposium Series 725. Washington, DC: American Chemical Society.

Sabatini, D.A., R.C. Knox, J.H. Harwell, and B. Wu. 2000. Integrated design of surfactant enhanced dnapl remediation: effective supersolubilization and gradient systems. Journal of Contaminant Hydrology 45, no. 1-4: 99-121.

Sandrin, S.K., M.L. Brusseau, J.J. Piatt, A.A. Bodour, W.P. Blanford, and N.T. Nelson. 2004. Characterizing spatial variability of in-situ microbial activity: Biotracer tests. Ground Water 42, no. 3: 374-383.

Seo, H.S., and J.E. McCray. 2002. Interfacial tension of chlorinated aliphatic DNAPL mixtures as a function of organic-phase composition. Environmental Science \& Technology 36, no. 6: 1292-1298.

Shiau, B., D.A. Sabatini, R.C. Knox, and J.H. Harwell. 1997. Surfactant-enhanced solubilization of mixed NAPL wastes at hill AFB: A case study. Abstracts of Papers of the American Chemical Society 213:50-ENVR.
Skold, M.E., G.D. Thyne, J.E. McCray, J.W. Drexler, and D. Macalady. 2008. Enhanced solubilization of a metalorganic contaminant mixture $(\mathrm{Pb}, \mathrm{Sr}, \mathrm{Zn}$, and $\mathrm{PCE})$ by cyclodextrin. Environmental Science \& Technology 42, no. 23: $8930-8934$.

Smith, M.M., J.A.K. Silva, J. Munakata-Marr, and J.E. McCray. 2008. Compatibility of polymers and chemical oxidants for enhanced groundwater remediation. Environmental Science \& Technology 42, no. 24: 9296-9301.

Taege, D.A. 2002. Field-scale study of the performance of air sparging for removing a dense nonqueous phase liquid (tetrachloroethylene) from a coastal plain aquifer, M.S. Thesis, Department of Civil \& Environmental Engineering, Michigan Technological University, Houghton, Michigan.

Tick, G.R., F. Lourenso, A.L. Wood, and M.L. Brusseau. 2003. Pilot-scale demonstration of cyclodextrin as a solubility-enhancement agent for the remediation of a tetrachloroethene-contaminated aquifer. Environmental Science \& Technology 37, no. 24: 5829-5834

U.S. Environmental Protection Agency (U.S. EPA). 2003. The DNAPL remediation challenge: Is there a case for source depletion? Expert panel on DNAPL remediation, Kavanaugh, MC. And PSC Rao, Co-chairs, EPA/600/R03/143. Office of Research and Development, Washington, DC.

U.S. Environmental Protection Agency (U.S. EPA). 2007. Research provides remediation tools to manage dense non-aqueous phase liquids (DNAPLs). Science in Action. Washington, DC: Office of Research and Development

van Antwerp, D.J., R.W. Falta, and J.S. Gierke. 2008. Numerical simulation of field-scale contaminant mass transfer during air sparging. Vadose Zone Journal 7, no. 1: 294-304.

Wang, X., and M.L. Brusseau. 1995. The simultaneous complexation of organic compounds and heavy metals by a modified cyclodextrin. Environmental Science \& Technology 29, no. 10: 2632-2635.

Wang, J.M., E.M. Marlowe, R.M. Miller-Maier, and M.L. Brusseau. 1998. Cyclodextrin-enhanced biodegradation of phenanthrene. Environmental Science \& Technology 32, no. 13: $1907-1912$.

Wojick, C.L. 1998. Comparison of field methods for assessing the performance of air sparging/soil vapor extraction, $\mathrm{Ph} . \mathrm{D}$. Dissertation. Department of Civil \& Environmental Engineering, Michigan Technological University, Houghton, Michigan.

Wood, A.L., and C.G. Enfield. 1999. In Situ Enhanced Source Removal. EPA/600/C-99/002.

Wood, A.L., and C.G. Enfield. 2005. Field Evaluation of Enhanced DNAPL Source Removal, USEPA Technical Report and SERDP Report CU-368, National Risk Management Research Laboratory, Office of Research and Development, U.S. EPA, Cincinnati, Ohio.

Wood, A.L., C.G. Enfield, F.P. Espinoza, M. Annable, M.C Brooks, P.S.C. Rao, D. Sabatini, and R. Knox. 2005 Design of aquifer remediation systems: (2) Estimating sitespecific performance and benefits of partial source removal. Journal of Contaminant Hydrology 81, no. 1-4: 148-166. 